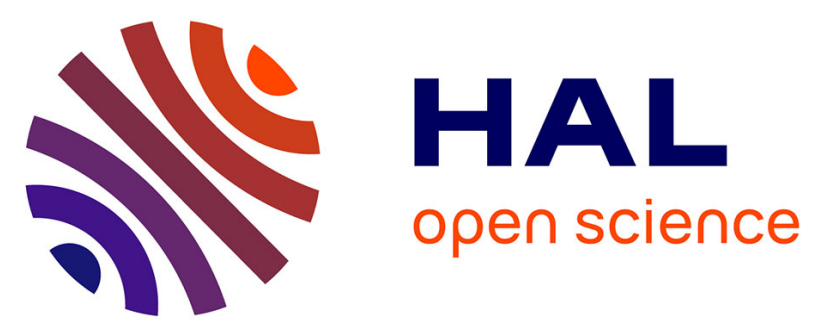

\title{
Tephrochronology of the Mont-Dore volcanic Massif (Massif Central, France): new 40Ar/39Ar constraints on the Late Pliocene and Early Pleistocene activity
}

Sébastien Nomade, Jean-François Pastre, Pierre Nehlig, Hervé Guillou, Vincent Scao, Stéphane Scaillet

\section{To cite this version:}

Sébastien Nomade, Jean-François Pastre, Pierre Nehlig, Hervé Guillou, Vincent Scao, et al.. Tephrochronology of the Mont-Dore volcanic Massif (Massif Central, France): new 40Ar/39Ar constraints on the Late Pliocene and Early Pleistocene activity. Bulletin of Volcanology, 2014, 76, pp.1-17. 10.1007/s00445-014-0798-6 . insu-00985769

\section{HAL Id: insu-00985769}

https://hal-insu.archives-ouvertes.fr/insu-00985769

Submitted on 30 Apr 2014

HAL is a multi-disciplinary open access archive for the deposit and dissemination of scientific research documents, whether they are published or not. The documents may come from teaching and research institutions in France or abroad, or from public or private research centers.
L'archive ouverte pluridisciplinaire HAL, est destinée au dépôt et à la diffusion de documents scientifiques de niveau recherche, publiés ou non, émanant des établissements d'enseignement et de recherche français ou étrangers, des laboratoires publics ou privés. 


\section{Tephrochronology of the Mont-Dore volcanic Massif (Massif}

\section{Central, France): new ${ }^{40} \mathrm{Ar} /{ }^{39} \mathrm{Ar}$ constraints on the Late Pliocene and Early Pleistocene activity}

Nomade Sébastien $^{(1)^{*}}$; Pastre Jean-François ${ }^{(2)}$; Nehlig, Pierre ${ }^{(3)}$, Guillou Hervé ${ }^{(1)}$, Scao Vincent $^{(1)}$; Scaillet Stéphane ${ }^{(4)}$.

(1) Laboratoire des Sciences du Climat et de l'Environnement, IPSL, CEA-CNRS-UVSQ, Avenue de la Terrasse, 91198 Gif-sur-Yvette Cedex, France

(2) Laboratoire de Géographie Physique, UMR 8591 CNRS, 1 place Aristide Briand, 92195 Meudon Cedex, France

(3) BRGM, 3 Avenue Claude Guillemin, BP 6009, Orléans Cedex 2, France

(4) Institut des Sciences de la Terre d'Orléans, CNRS-Université d'Orléans, 45067 Orléans Cedex 2, France

6947words

10 figures

1 table

2 online supplementary tables

\footnotetext{
* Corresponding author: sebastien.nomade@1sce.ipsl.fr, Tel: +33 (0)1 698235 51; Fax: +33 (01) 69823568
} 


\section{Abstract}

The Mont-Dore Massif $\left(500 \mathrm{~km}^{2}\right)$, the youngest stratovolcano of the French Massif Central, consists of two volcanic edifices: the Guéry and the Sancy. To improve our knowledge of the oldest explosive stages of the Mont Dore Massif, we studied ${ }^{40} \mathrm{Ar} /{ }^{39} \mathrm{Ar}$ dated (through single-grain laser and step-heating experiments) eleven pyroclastic units from the Guéry stratovolcano. We demonstrate that the explosive history of the Guéry can be divided into four cycles of explosive eruption activity between 3.09 and 1.46 Ma (G.I to G.IV). We have also ascertained that deposits associated with the 3.1-3.0 Ma rhyolitic activity, which includes the $5 \mathrm{~km}^{3}$ "Grande Nappe" ignimbrite, is not recorded in the central part of the Mont-Dore Massif. All the pyroclastites found in the left bank of the Dordogne River belong to a later explosive phase (2.86-2.58 Ma, G.II) and were channelled down into valleys or topographic lows where they are currently nested. This later activity also gave rise to most of the volcanic products in the Perrier Plateau (30 km east of the Mont-Dore Massif); three quarters of the volcano-sedimentary sequence (up to $100 \mathrm{~m}$ thick) was emplaced within less than $20 \mathrm{ky}$, associated with several flank collapses in the northeastern part of the Guéry. The age of the "Fournet flora" $(2.69 \pm 0.01 \mathrm{Ma})$ found within an ash bed belonging to G.II suggests that temperate forests already existed in the French Massif Central before the Pliocene/Pleistocene boundary. The Guéry's third explosive eruption activity cycle (G.III) lasted between 2.36 and 1.91 Ma. It encompassed the Guéry Lake and Morangie pumice and ash deposits, as well as seven other important events recorded as centimetric ash beds some 60 to $100 \mathrm{~km}$ southeast of the Massif in the Velay region.

We propose a general tephrochronology for the Mont-Dore stratovolcano covering the last 3.1 My. This chronology is based on forty-four ${ }^{40} \mathrm{Ar} /{ }^{39} \mathrm{Ar}$-dated events belonging to eight explosive eruption cycles each lasting between 100 and $200 \mathrm{ky}$. The occurrence of only one 
pumice deposit in the 800 ky period between 1.9 and 1.1 Ma suggests that volcanic explosive activity was strongly reduced or quiescent.

\section{Keywords}

Mont-Dore, Plio-Pleistocene, ${ }^{40} \mathrm{Ar} /{ }^{39} \mathrm{Ar}$, pyroclastic activity, flank collapse 


\section{Introduction}

Two large stratovolcanoes are known in the French Massif Central: the Cantal and the MontDore massifs (Fig. 1a). The youngest of these edifices (Mont-Dore) covers an area of 500 $\mathrm{km}^{2}$, rests on the Variscan basement (Cantagrel and Baubron 1983) and was active between 3.1 Ma and $200 \mathrm{ka}$. The total volume erupted from the Mont-Dore Massif has been estimated at between $220 \mathrm{~km}^{3}$ and $70 \mathrm{~km}^{3}$ (Brousse 1971; Vincent 1980; Cantagrel and Baubron 1983; Cantagrel and Briot 1990; Figs. 1 and 2). The massif is composed of two coalescent stratovolcanoes: the Guéry and the Sancy (Baubron and Cantagrel 1980). The diversity and the wide dispersion of its pyroclastic products have been used for stratigraphic correlation and dating of the Plio-Pleistocene formations in the French Massif Central and elsewhere (Pastre and Cantagrel 2001; Brauer et al. 2007; Pastre et al. 2007; Roulleau et al. 2009; Nomade et al. 2013). While the explosive history of the younger Sancy stratovolcano is well constrained (Pastre et al. 2007; Nomade et al. 2010; Nomade et al. 2012), the older Guéry stratovolcano is only partially known mainly through its distal products found in the Perrier Plateau (Pastre 2004; Bernard et al. 2009; Nomade et al. 2013; Fig. 2) as well as in several Early Pleistocene sequences from the Velay region (Nomade et al. 2013).

In order to refine and reconstruct the geological evolution of the Guéry complex, we dated 11 volcanic units using the ${ }^{40} \mathrm{Ar} /{ }^{39} \mathrm{Ar}$ method and integrating the new ages into a database of twenty-four ${ }^{40} \mathrm{Ar} /{ }^{39} \mathrm{Ar}$ ages covering the Late Pliocene to Early Pleistocene activity of MontDore. It is now possible to construct a robust and coherent tephrostratigraphy integrating both distal and proximal records..

\section{The Guéry stratovolcano: geological background}


The volcanic history of the early Mont-Dore Massif started between 6.0 and 3.1 Ma with the emplacement of a few dispersed basanite and more differentiated volcanic products (Cantagrel and Baubron 1983; Pastre and Cantagrel 2001). The pyroclastic activity of the Guéry stratovolcano sensu stricto started as early as $3.09 \pm 0.01 \mathrm{Ma}^{1}$ as shown by the recent ${ }^{40} \mathrm{Ar} /{ }^{39} \mathrm{Ar}$ age on the lowermost quartz-rich rhyolitic Plinian fall deposits (RP1: Pastre 2004; Nomade et al. 2013). The following event was the major fibrous pumice-bearing rhyolitic ignimbrite ("Grande Nappe", GN hereafter) found in the Perrier Plateau only few metres above the RP1 unit (Nomade et al. 2013). The GN is the largest pyroclastic formation of the Mont-Dore Massif with an estimated volume of $5 \mathrm{~km}^{3}$ (Vincent 1980) and was synchronous with the formation of a cryptic "Haute Dordogne" caldera (Vincent 1979; Mossand et al. 1982; Mossand 1983). However, if this caldera does exist, its morphology is no longer visible because concealed by post-caldera magmatic intrusions and the more recent activity of the

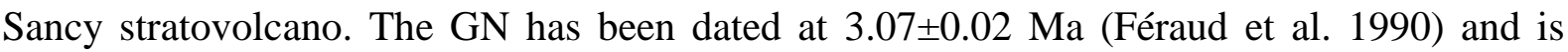
supposed to crop out at the base of the Vendeix-Bourboule pyroclastic succession located on the left bank of the Dordogne River (Pastre and Cantagrel 2001). Following on the GN, several trachytic pyroclast events recorded in the Perrier Plateau are known to have occurred between 2.76 $\pm 0.01 \mathrm{Ma}$ and 2.58 $\pm 0.01 \mathrm{Ma}$ (Pastre, 2004; Nomade et al. 2013). It is suggested that the Pessy-Pregnoux trachytic pumice also belongs to this activity (Pastre and Cantagrel 2001). The next pyroclastic cycle occurred from around $2.36 \mathrm{Ma}$ to $1.90 \mathrm{Ma}$ (Nomade et al. 2013; Fig. 1b) and evidence of this activity is found around the Guéry Lake (2.06 $\pm 0.06 \mathrm{Ma}$, Féraud et al. 1990; Fig. 2 and Table 1) and in the Morangie area (i.e. 1.92 \pm 0.02 Ma, Féraud et al. 1990). The last explosive phase, represented by the Creux de Peyrolles and dated at 1.42 \pm 0.10 Ma by Lo Bello (1988), has been re-assessed at $1.46 \pm 0.01$ Ma by Nomade et al. (2013) (Fig. 3).

\footnotetext{
1 The uncertainties are quoted at $1 \sigma$ throughout the text (Renne et al. 2009), and normalized to FCs standard at 28.02 Ma (Renne et al. 1998).
} 
The explosive history outlined above is almost entirely based on the dating of distal pyroclastic deposits and not on the well-mapped pyroclastic pile exposed around the Vendeix stream in the central part of the Mont-Dore Massif (see Pastre and Cantagrel [2001] for detailed stratigraphic sections). As a consequence, correlation between the distal deposits and the various pyroclastic outcrops and sections in the central part of the Massif is based on mineralogical and geochemical similarities (Pastre and Cantagrel 2001).

\section{Material and methods}

\section{Sample description}

Eleven pyroclastic horizons were investigated. Details including sample number, local name, GPS location, mineralogical paragenesis, mechanisms of emplacement are summarized in supplementary Table 1 .

\section{$\underline{\text { Proximal pyroclastic units }}$}

Four of the six samples we studied from the central part of the Guéry stratovolcano (08MD01, 08MD-03 to -05 , see supplementary table T1) were collected from deposits along the Vendeix stream on the left bank of the Dordogne River, south of La Bourboule (Fig. 2); the detailed cross-section of this area can be found in Figure 7 of Pastre and Cantagrel (2001). Based on their mineralogy and chemistry, the four pyroclastic units are considered to belong to the two oldest Guéry explosive cycles (Pastre and Cantagrel 2001).

Of the four samples taken in the central part of Guéry, sample 08MD-05 from Bourboule bas (BN bas hereafter) is a trachytic pumice and ash flow deposit (PAF hereafter) lying directly on Paleozoic granite; it is known as the "Infrabasale unit" (Ménard 1979) and regarded as the oldest pyroclastic unit of the proximal areas. Sample 08MD-01 from the 
Vendeix/Siège rhyolitic PAF (Pastre and Cantagrel, 2001) crops out only $500 \mathrm{~m}$ away from 08MD-05 at an elevation of $1026 \mathrm{~m}$ a.s.l. Because of its rhyolitic composition as well as the presence of green amphibole (edenite), typical of the early activity of the Guéry, Pastre and Cantagrel (2001) considered that this unit is an intracaldera equivalent of the "Grande Nappe" ignimbrite dated at 3.07 \pm 0.02 (Féraud et al., 1990). Sample 08MD-03 from east of the Vendeix stream (1000 m a.s.l.) is a trachytic PAF (V1000 hereafter), and Sample 08MD-04 from Bourboule haut (BN haut hereafter) at $1122 \mathrm{~m}$ a.s.l., is the uppermost pyroclastic unit we sampled in this area.

Sample 08MD-06, a trachytic PAF from 1040 m a.s.1., was collected at Pessy-Pregnoux (PP hereafter) northeast of the Vendeix section (Fig. 2). This unit is thought to result from the first explosive activity following those of the pyroclastic units we sampled along the Vendeix stream (Pastre and Cantagrel 2001).

Sample MD08-26 (see Supplementary Table 1) was collected from within a trachytic PAF unit, about $30 \mathrm{~m}$ thick, exposed south of the Guéry Lake (Fig. 2) and dated at 2.04 $\pm 0.06 \mathrm{Ma}$ by Féraud et al. (1990). This unit corresponds to the Guéry's middle pyroclastic cycle according to Pastre and Cantagrel, (2001).

\section{$\underline{\text { Distal pyroclastite samples }}$}

We dated four new pyroclastic units within the Perrier Plateau succession (Fig. 3), all of which are complementary to our initial chronostratigraphic study (Nomade et al. 2013).

Sample PER 142 (Fig. 3b), a trachytic ash deposit of about $1 \mathrm{~m}$ in thickness also known as the Fournet tuffite (Pastre 2004) is exposed to the northeast of the villages of Boissac and Pardines (Fig. 3b). The deposit is remarkable in that it contains a well-preserved flora composed of Fagus, Quercus and Carpinus indicative of temperate conditions (Pastre 1987). Its pollen spectrum also includes European conifers, haploxylon type Pinus and some rare 
Sequoias (Pastre 2004). Stratigraphically, this ash bed is below the first of the four debris avalanches preserved in the Perrier plateau and recently dated at 2.58 $\pm 0.01 \mathrm{Ma}$ (Nomade et al. 2013) (Fig. 3b) . Along with the temperate flora from Sablou de Lossa (Bout 1933; Bout and Marty 1936), this unit contains some of the best-preserved end-Pliocene flora in France.

Samples PER 139, 144 and 145 (Fig. 3a, b; supplementary Table T1) are located within a $500 \mathrm{~m}$ radius of one another. PER 139 corresponds to the F5b unit described by Pastre (2004) and consisting of large trachytic pumices reworked in the lowermost coarse-pebble alluvium of the Perrier succession that followed the RP1 unit (3.09 \pm 0.01 Ma; Nomade et al. 2013) (Fig. 3b). PER 144 and 145 are respectively from trachytic-Plinian and ash-fall deposits cropping out at the Perrier Grottes site,(Fig. 3a, b). These two units lie stratigraphically below the C1 debris avalanche, above the F5b unit discussed above (Fig. 3b).

The last sample, "CEY" (see supplementary table T1), is a latitic fine ash bed collected near Ceyssac, $100 \mathrm{~km}$ southeast of the Guéry stratovolcano (Fig. 3c). This ash bed is found above the "mastodonte sandstone" (Boule, 1892) and below the Cey-1 pollen assemblage with an estimated age between 1.7 and 2.5 Ma (Ablin 1991; Defive et al. 2005; Leroy et al. 2011) (Fig. 3c). The peculiar composition of this ash bed (latite) (see supplementary Table 1) is only known SE of the Guéry stratovolcano at the base of Fontaine salée volcanic sequence

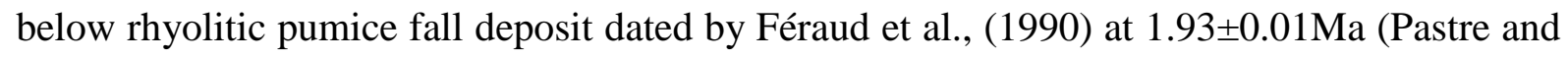
Cantagrel, 2001). The Ceyssac section is covered by two lava flows dated by K/Ar at

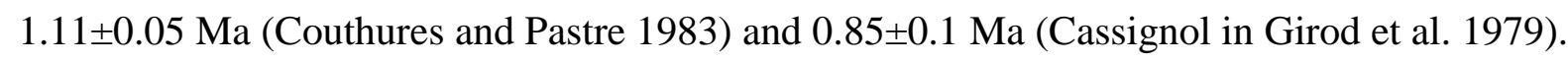

\section{Sample preparation and the ${ }^{40} \mathrm{Ar} /{ }^{39} \mathrm{Ar}$ method}

Pristine sanidine crystals ranging in size from 250 to $400 \mu \mathrm{m}$ were concentrated through several density separations using Lithium Meta Tungstate (LMT) heavy liquid. The crystals were handpicked under a binocular microscope and then gently leached for 5 minutes in a $7 \%$ 
HF acid solution in order to remove adhered groundmass. After leaching and sizing, between a 20 and 30 grains were finally selected for each sample. For the Ceyssac tephra, after removal of all the milky crystals under the binocular microscope, about $60 \mathrm{mg}$ of pristine plagioclase (150-250 $\mu \mathrm{m})$ was selected.

The sanidine samples were irradiated in the $\beta 1$ tube of an Osiris reactor (CEA Saclay, France; Irr. 12, 23, 31 and 35 for respective durations of 50, 120, 90 and $120 \mathrm{~min}$ ). Following their irradiation, single crystals from each sample were individually transferred into a stainless-steel sample holder and then loaded into a differential vacuum Cleartran ${ }^{\odot}$ window. After a further slight leaching using a $25 \mathrm{~W} \mathrm{CO}_{2}$ laser $\left(\operatorname{Synrad}^{\odot}\right)$ at $2.5 \%$ of the full laser power, the single crystals were fused at about $15 \%$ of the full laser power. For the Ceyssac tephra, about $30 \mathrm{mg}$ of the plagioclase was step-heated using a defocused laser beam (3\% to $15 \%$ of the laser power). Ar isotopes were analysed using a VG5400 mass spectrometer equipped with a single ion counter (Balzers ${ }^{\odot}$ SEV 217 SEN) following the procedure outlined in Nomade et al. (2010). Neutron fluence (J) was monitored by co-irradiation of Alder Creek Sanidine (ACs-2; Nomade et al. 2005). The J values were calculated using an age of 1.193 Ma (Nomade et al. 2005) and the total decay constant of Steiger and Jäger (1977). Recent revisions of decay and monitor constants suggest values of about $0.64 \%$ (Kuiper et al. 2008; 1.201 Ma for ACs-2) and 1.0\% (Renne et al. 2011; 1.205 Ma for ACs-2) older. This implied difference in the calibrated age is negligible for our samples (about 10 to $20 \mathrm{ky}$ ). However, to be consistent with the last geological time scale published in 2012 and which adopted the Kuiper et al. (2008) calibration (see Schmitz 2012), we recalculated all our data according this calibration (Table 1). Mass discrimination correction was monitored by weekly measurement of the air argon (see the full experimental description in Nomade et al. 2010).

\section{${ }^{40} \mathrm{Ar} /{ }^{39} \mathrm{Ar}$ results}


Our age results are summarized in Table 1 along with a compilation of all the published ${ }^{40} \mathrm{Ar} /{ }^{39} \mathrm{Ar}$ ages from the Mont-Dore Massif pyroclastic units. Full analytical details for the individual crystal experiments and plagioclase step-heating are given in the supplementary Table T2. Data reduction and isochron regressions were calculated using ArAr CALC (Koppers 2002). Age-probability density spectra with individual single crystal ages $(1 \sigma)$, plateau-age spectra for the Ceyssac tephra and the corresponding isochron for each sample are shown in Figures 4 to 7 . The cutoff for a statistically homogeneous sanidine crystal population was taken for a probability of fit (P) of 0.05 (95\% confidence).

\section{Bourboule-Vendeix section (08MD-01, 08MD-03-05)}

The Bourboule-Vendeix section ranges in age from 2.86 $\pm 0.05 \mathrm{Ma}(\mathrm{MSWD}=1.0, \mathrm{P}=0.5)$ to 2.67 $\pm 0.01 \mathrm{Ma}(\mathrm{MSWD}=1.6, \mathrm{P}=0.1)$ (Fig. 4). Corresponding age-probability density spectra indicate that three pyroclastic units (represented by samples 08MD-05, MD-01 and MD03) contain xenocrysts (Fig. 4). The effect of this contamination is evidenced by complex tailed probability spectra. Nevertheless, juvenile crystals in all three cases induce a prominent mode that enabled respective ages of $2.86 \pm 0.01 \mathrm{Ma}, 2.74 \pm 0.01 \mathrm{Ma}$ and $2.67 \pm 0.01 \mathrm{Ma}$ to be calculated. Sample 08MD-04 is dominated by juvenile crystals with a mean age of $2.73 \pm 0.01$ Ma $(M S W D=1.3, P=0.3)\left(\right.$ Fig. 4). The analysed crystals displayed high radiogenic ${ }^{40} \mathrm{Ar}^{*}$ and so it was not possible to obtain precise atmospheric initial ratios (Fig. 4 and Table 1). Despite this limitation, the ages derived from inverse isochrons are identical to that calculated from the most probable mode (Table 1).

\section{Pessy-Pregnoux and Guéry (08MD-06, MD-26)}

Sample 08MD-06 (PP) is dated at 2.70 $\pm 0.01 \mathrm{Ma}(\mathrm{MSWD}=1.5, \mathrm{P}=0.1)$, similar to the dates from the Vendeix stream pyroclastic units, whereas Sample 08MD-26 from the PAF unit 
south of the Guéry Lake is younger (i.e. 2.08 $\pm 0.01 \mathrm{Ma}$; MSWD $=0.8, \mathrm{P}=0.6$ ). With the exception of a single crystal in Sample 08MD-06 (Fig. 4), the corresponding age-probability density spectra indicate a simple mode. The corresponding isochron plots display initial ${ }^{40} \mathrm{Ar} /{ }^{36} \mathrm{Ar}$ intercept values identical to the current atmospheric one and so indicate no excess argon component (Fig. 4; Table 1).

\section{Perrier Plateau distal deposits}

The four new ages for the Perrier Plateau units range from 2.69 $\pm 0.01 \mathrm{Ma}(\mathrm{MSWD}=1.1, \mathrm{P}=$ $0.4)$ to $2.59 \pm 0.01 \mathrm{Ma}(\mathrm{MSWD}=0.7, \mathrm{P}=0.7)$. Corresponding probability diagrams suggest the presence of xenocrysts, as indicated by tailed age distributions (Sample PER 145) and multi-modes (Samples PER 142, PER 139; Fig. 6). However, juvenile crystals are so prominent in all cases that calculating reliable ages is feasible, especially as none of the samples have excess ${ }^{40} \mathrm{Ar} *$ (the isochrons show atmospheric ${ }^{40} \mathrm{Ar} /{ }^{36} \mathrm{Ar}$ initial intercepts; Fig.6). The date of Sample PER $142(2.69 \pm 0.01 \mathrm{Ma})$ gives the best age estimation for the flora found in this unit. The ages of the two trachytic fall deposits exposed at the "Perrier Grottes" are respectively 2.60 $\pm 0.01 \mathrm{Ma}(\mathrm{MSWD}=1.2, \mathrm{P}=0.2)$ and $2.59 \pm 0.01 \mathrm{Ma}(\mathrm{MSWD}=$ $0.7, \mathrm{P}=0.7)$

\section{Ceyssac tephra}

The plagioclase from the Ceyssac tephra gives an age of $1.91 \pm 0.01 \mathrm{Ma}(\mathrm{MSWD}=0.9, \mathrm{P}=$ 0.5). Step-heating experiments yielded concordant spectra, including $100 \%$ of the gas released (Fig. 5). The ${ }^{40} \mathrm{Ar} /{ }^{36} \mathrm{Ar}$ intercept, determined rather imprecisely, is atmospheric $(268 \pm 38)$ indicating no excess argon.

\section{Discussion}




\section{Chronology of the Guéry explosive activity}

Our new ${ }^{40} \mathrm{Ar} /{ }^{39} \mathrm{Ar}$ ages range from 2.86 $\pm 0.01 \mathrm{Ma}$ to $1.91 \pm 0.02 \mathrm{Ma}$ (Table 1). Along with the already published ages, this gives a total of 24 pyroclastic units from the Guéry that have now been dated (Table 1). Consequently we have been able to establish a tephrochronology and illustrate the timing of the successive cycles of explosive eruption activity using a probability diagram (Fig. 8). The overall explosive history of this edifice lasted about $1.6 \mathrm{My}$, between 3.1 Ma and 1.5 Ma, with four cycles referred hereafter as G.I, G.II, G.III and G.IV.

In this work we did not sample and date deposits belonging to the G.I. The two oldest units that we have sampled in the proximal regions of the Guéry, are deposited directly on granite bedrock in the inner part of the Guéry, and dated at 2.86 $\pm 0.01 \mathrm{Ma}(08 \mathrm{MD}-05)$ and $2.74 \pm 0.01$ Ma (08MD-01). These units were originally considered to belong to G.I (Ménard et al. 1979; Pastre 1987; Pastre and Cantagrel 2001), therefore to be older than 3 Ma (see Fig. 9). The lack of deposit related to the first explosive eruption cycle of the Guéry in the proximal areas is probably due to the formation and following subsidence of the "Haute Dordogne" caldera. According to the age we obtained for the Vendeix/Siege PAF unit (08MD-01) and despite its chemical, lithological and mineralogical similarities with the GN event (See supplementary Table 1), this eruption corresponds to a rhyolitic activity within the G.II trachytic cycle. The contradiction between previous work and ours is due mainly to the difficulties involved in undertaking classical stratigraphic studies in complex stratovolcanoes without good chronological control and/or clear field relationships. Indeed, the small volumes of pyroclastic deposits $\left(<1 \mathrm{~km}^{3}\right)$ in a volcanotectonic context like the one we studied tend to be channelled down valleys and into topographic lows and are thus only found in a restricted area (cf. Paquereau Lebti et al., 2006). The paleotopographic control and channelling of the pyroclastic products are known for the youngest part of the Massif (Nomade et al. 2012) and it seems reasonable to hypothesise the same for the oldest part of the volcano as suggested by the 
V1000 pumice flow (08MD-03) dated at 2.67 \pm 0.01 Ma. This unit is located at an altitude of $1025 \mathrm{~m}, 100 \mathrm{~m}$ below BN haut (08MD-04) at $1122 \mathrm{~m}$ a.s.l. and dated at 2.73 $\pm 0.01 \mathrm{Ma}$, which would indicate that the V1000 unit is nested within older units located at a higher altitude (see Fig. 9). Another argument is given by the PP unit (2.70 $\pm 0.01 \mathrm{Ma}, 1039 \mathrm{~m})$ that crops out 85 $\mathrm{m}$ lower than the older BN haut unit $(2.73 \pm 0.01 \mathrm{Ma})$ (Fig. 2). It had originally been suggested, based on the work of Duffell (1999), that the PP unit was emplaced between 2.60 and 2.55 Ma (Fig. 9). The 2.70 $\pm 0.01 \mathrm{Ma}$ age of this unit is therefore older than expected, although Pastre and Cantagrel (2001) had already suggested that it belonged to the same explosive cycle (G.II). Excluding, unit we dated at 2.86 Ma, our data show that the 100- to locally 200-m-thick pyroclastic pile exposed on the left bank of the Dordogne River was emplaced between $2.74 \pm 0.01 \mathrm{Ma}$ and $2.67 \pm 0.01 \mathrm{Ma}$.

The distal products of the Perrier Plateau that we dated range from 2.69 $\pm 0.01 \mathrm{Ma}$ (MSWD $=1.1, \mathrm{P}=0.4)$ and $2.59 \pm 0.01 \mathrm{Ma}(\mathrm{MSWD}=0.7, \mathrm{P}=0.7)$. Apart from two rhyolitic deposits belonging to G.I (PER 128, and Roca Neyra, Fig. 3b, Table 1), together about $10 \mathrm{~m}$ thick, the entire Perrier Plateau pyroclastic sequence, locally as thick as $150 \mathrm{~m}$, was emplaced during the G.II cycle (i.e. 2.76 \pm 0.01 Ma (Sample PER 105) to 2.58 \pm 0.01 (Perrier Avalanche C1, Nomade et al., 2013) (Fig. 8, Table 1 and supplementary table 1). The end of the G.II cycle corresponds to several major events that probably occurred within less than $20 \mathrm{ky}$, starting with the two eruptions recorded in the Perrier Grottes area, respectively dated at $2.60 \pm 0.01$ Ma and 2.59 $\pm 0.01 \mathrm{Ma}$ and ending with four debris avalanches (Pastre 2004; Bernard et al. 2009) which fossilized the Perrier plateau sequence (fig. $3 a, b$ ). If the debris avalanches $C 1$ to C3 have been emplaced rapidly (Pastre 2004; Bernard et al. 2009) around 2.58 Ma (Nomade et al., 2013), the unconformity observed between the third (C3) and fourth (C4) avalanches suggests a period of fluvial incision (Bernard et al. 2009). Excluding C4, the short period of activity between 2.61 and 2.58 Ma represents the major part of the volcanic products, locally 
$100 \mathrm{~m}$ thick, found in the Perrier Plateau. The activity at the end of G.II is related to the sudden collapse and resulting debris avalanche coming from the northeastern part of the Guéry (Besson, 1978; Morel, 1987; Pastre, 2004; Bernard et al. 2009), which is why this activity is not found on the left bank of the Dordogne River (Fig. 8). The volcanic products from the Guéry volcano, destabilized at the Plio-Pleistocene boundary, were channelled down an E-W valley known as the paleo-Couze Pavin River (Bernard et al. 2009). G.II and G.I are distinct in term of duration, eruptive style and emitted products. G.I is shorter, lasted from 3.09 and 3.02 Ma with exclusively rhyolitic products and associated with the formation of a caldera. G.II is constituted of more eruptions (a least ten) of both trachytic and rhyolitic composition and lasted from 2.86 and $2.59 \mathrm{Ma}$. This highly explosive activity without caldera formation during G.II favoured the edification of a high volcanic structure, which collapsed westward several times, the first collapse being estimated at $2.58 \mathrm{Ma}$ ago. It is currently difficult to have a volumetric evaluation of the total product emitted during G.II but the local thickness of several units exceeding $20 \mathrm{~m}$ in the proximal areas suggest eruptions in the order of $1 \mathrm{~km}^{3}$ and a total volume that may exceed the one emitted during G.I.

The age of the Guéry PAF unit (i.e. $2.08 \pm 0.01 \mathrm{Ma}$ ) is consistent with the age given by Féraud et al. (1990). The unit is part of the Guéry's third explosive cycle (G.III), which is not found west of the Mont-Dore Massif where the Vendeix 1000 unit $(2.67 \pm 0.01 \mathrm{Ma})$ is immediately overlain by Sancy pyroclastic units dated at between 1.10 and $1.01 \mathrm{Ma}$ (Nomade et al. 2012; Fig. 9). According to the ages, chemistry and mineralogical assemblages (see supplementary Table 1) published on the tephra layers found in the sedimentary fill of the Senèze maar (ranging from 2.18 to 2.08 Ma; Nomade et al. 2013; Fig. 8), the Guéry PAF unit is the proximal equivalent of these events. The Senèze and Chilhac ash deposits suggest that the beginning of G.III encompassed at least six large trachytic eruptions (Fig. 8), but only one is currently known in the proximal record of the Guéry stratovolcano. The Guéry PAF deposit 
is found sandwiched between two pyroclastic units with large phonolitic blocks that were not sampled. The age for the latitic Ceyssac tephra is $1.91 \pm 0.01 \mathrm{Ma}(\mathrm{MSWD}=0.9)$. This age agrees with the one obtained by Féraud et al. (1990) for the Morangie rhyolitic pumice deposit that overlies the only latitic plagioclase pumices deposit known during the G.III activity of the Guéry (Cantagrel and Pastre, 2001). These two units mark the end of the G.III cycle (Fig. 8 and Table 1). Furthermore, the age of the Ceyssac tephra is the best radiometric age for the large mammalian fauna described by Boule (1892). G.III and G.II each lasted longer than G.I and display larger chemical diversity. Furthermore, the occurrence of deposits housing phonolite blocks below and above the Guéry PAF suggests that trachytic products emitted during G.III were associated temporally to the emission of phonolitic products. This hypothesis is reinforced by the ages between 2.2 and 2.1 Ma obtained for the phonolithic domes found NE of the stratovolcano (Cantagrel and Baubron, 1983; Cocherie et al., 2009) G.III ended 1.9 Ma ago, with at least one large eruptive event of latitic composition.

Almost $400 \mathrm{ky}$ after the end of the G.III cycle, the presence of trachytic pumice interbedded in alluvial beds and dated at $1.46 \pm 0.01 \mathrm{Ma}$ (Creux de Peyrolles) in the eastern part of the Perrier Plateau (Nomade et al., 2013), suggests a more recent but modest pyroclastic activity (G.IV; Fig. 8). This activity is not found in the proximal area of the Guéry (Fig. 8).

\section{About the age of the Fournet Flora}

The paleo-flora sites, as well as the numerous large-mammal fauna found in the Perrier Plateau area (Nomade et al. 2013), are local indicators of the paleoenvironmental mid-latitude and altitude conditions at the Pliocene-Pleistocene transition. The global temperature in the northern hemisphere gradually dropped during the Late Pliocene, along with an increase in glacial activity (Haug et al. 2005; Raymo et al. 2006; Lisiecki and Raymo 2007). Climates 
became progressively cooler and drier, with the warm and humid forest habitat being replaced by savanna-like environments favourable to the spread of large herbivores. According to the $2.69 \pm 0.01 \mathrm{Ma}$ age obtained for the flora in the Fournet tuffite unit, it would appear that the warm and humid forest habitat had already decreased significantly at this early period corresponding to one of the first marked large climatic oscillations known as G5 (2.72 to 2.69 Ma; Lisiecki and Raymo 2005; Fig. 10). This new date is in agreement with the gradual increase of several taxa (Gazella borbonica, Leptobos elatus and bravardi) considered as inhabiting open land, and the gradual decrease of tropical forests during the same period (i.e. 2.8-2.6 Ma; Nomade et al. 2013). The end-Pliocene faunal and floral assemblages found in the vicinity of the Perrier Plateau generally indicate the increasing importance of large grazing animals and the presence of woodlands populated with mostly temperate forest taxa, suggesting that the fauna and flora in France reacted rapidly to the environmental changes at the onset of the Northern Hemisphere glaciation between 2.6 and 2.7 Ma (Raymo et al. 2006; Lisiecki and Raymo 2007).

\section{The Mont-Dore Massif tephrostratigraphy: a 2.8 My long story}

Overall, our research group has produced and published thirty-eight ${ }^{40} \mathrm{Ar} /{ }^{39} \mathrm{Ar}$ ages (including those presented above) covering the pyroclastic activity of the Mont-Dore Massif (Table 1). In Figure 10 we plot all the available ${ }^{40} \mathrm{Ar} /{ }^{39} \mathrm{Ar}$ ages for this pyroclastic activity and present a general probability distribution built using all the analysed single crystals to illustrate the period. On the left we show the Late Pliocene to Early Pleistocene sites of megafauna (Nomade et al. 2013) and flora (this study) that we dated using the volcanic products from the Guéry stratovolcano; they are local indicators of the paleoenvironmental conditions which have been precisely dated and compared with the $\delta^{18} \mathrm{O}$ benthic stacks of Lisiecki and Raymo (2005) that represent a global climatic record. 
A total of eight explosive cycles are recognized for the Mont-Dore Massif (Fig. 10). The duration, the number of events, and the volume of emitted products, as well as eruptive style vary greatly from one cycle to another (see details above for the Guéry stratovolcano and Nomade et al. 2012 for the Sancy stratovolcano). Our compilation highlights the fact that both proximal and distal records are crucial to achieve a comprehensive reconstruction of the explosive activity in complex and old volcanic edifices. This is particularly true for the oldest Guéry stratovolcano that underwent several erosional phases between each explosive eruption cycles but also between the end of its activity 1.46 Ma ago and the beginning of the Sancy activity 1.1 Ma ago. Furthermore it is important to notice that the SW part of this stratovolcano was destroyed or sealed by the formation of the Sancy (Fig. 2). The 2.8 My activity of the Mont-Dore Massif included periods of relative quiescence periods where no deposits have been found (Fig. 10). These quiescence periods may be real dormancy or periods of reduced intensity of the explosive eruptive activity with limited volumes and therefore poorly dispersed products covered by younger ones or simply removed by erosion. Current knowledge and geological survey of the two volcanoes are insufficient to fully understand these periods. However, it is worth mentioning that the longest of these periods occurred between the G.III and G.IV cycles (about $400 \mathrm{ky}$ ) and the G.I and C.I cycles (about $350 \mathrm{ky}$ ), thus between the Guéry and Sancy volcanic activities (Fig. 10). In general, these periods of relative quiescence between phases of intense explosive construction, both for the Guéry and the Sancy, did not exceed 140 ky (Fig. 10); the 200 ky period between G.II and G.III is unusually long and may be related to a major disturbance following the major flank collapses and resulting mass rockslides recorded in the Perrier Plateau at the Plio-Pleistocene boundary (Fig. 10). These events deeply modified the Guéry topography and were followed by the emplacement (dated between 2.40 and $2.10 \mathrm{Ma}$ ) of large rhyolitic and phonolitic 
intrusions in the central part of the volcano (e.g. Puy de Chantauzet, Roche Sanadoire; Bellon et al. 1972; Mossand et al. 1982; Cantagrel and Baubron 1983; Cocherie et al. 2009).

\section{Conclusions}

The eleven new ${ }^{40} \mathrm{Ar} /{ }^{39} \mathrm{Ar}$ ages from the Late Pliocene and Early Pleistocene pyroclastic units of the Mont-Dore Massif presented in this contribution are the first high-precision ${ }^{40} \mathrm{Ar} /{ }^{39} \mathrm{Ar}$ datings of the proximal areas of the Guéry stratovolcano. Several major conclusions can be drawn on the Guéry's history and also concerning the 2.8 My long activity of the Mont-Dore Massif tephrochronology:

1) Four distinct cycles of explosive activity are now defined for the Guéry stratovolcano: G.I (3.09 to 3.02 Ma); G.II (2.86 to 2.58 Ma); G.III (2.36-1.91 Ma) and G.IV (1.46 Ma).

2) The initial rhyolitic activity from the Guéry stratovolcano, including the Grande Nappe ignimbrite forms the first cycle (G.I) which lasted between 3.09 and $3.02 \mathrm{Ma}$. The deposits of this early activity are not present in the central part of the Guéry volcano likely as a result of the collapse of the Haute-Dordogne caldera.

3) The Bourboule nappe on the left bank of the Dordogne River thought to be associated with the initial activity of the Guéry, is dated between 2.86 and $2.69 \mathrm{Ma}$. All its pyroclastic units thus belong to the second explosive eruption cycle (G.II) and composed of pumices and ash flow deposits channeled down valleys and into topographic lows.

4) New ${ }^{40} \mathrm{Ar} /{ }^{39} \mathrm{Ar}$ ages from the Perrier Plateau volcano-sedimentary sequence show that this 100-m-thick succession, emplaced mainly between 2.61 and 2.58 Ma and followed by major flank collapses (debris-avalanches) in the northeastern part of the Guéry, belongs to the end of the G.II cycle. 
5) The age of the Fournet ash and associated flora demonstrates that the French Massif Central was covered by temperate forests with only relics of tropical taxa (Bout and Marty, 1936; Pastre 1987) as early as 2.69 Ma.

6) The third explosive eruption cycle (G.III) is found only in two restricted areas of the Guéry; one around the Guéry Lake $(2.08 \pm 0.01 \mathrm{Ma})$ and the other near the Morangie area $(1.92 \pm 0.01 \mathrm{Ma})$. The cycle comprises several plinian eruptions ranging in age between 2.36 to 1.91 Ma and currently known only in the Velay region (i.e. Chilhac, Senèze maar and Ceyssac) about 60 to $100 \mathrm{~km}$ southeast of the Guéry.

7) The Mont-Dore Massif has undergone eight pyroclastic phases over the last 3.1 My. The last two pyroclastic cycles from the Guéry and Sancy stratovolcanoes (respectively G.IV at 1.46 Ma and C.IV around $300 \mathrm{ka}$ ) correspond to small-volume units found solely as distal deposits. The two main stratovolcanoes forming the Massif are separated in time by a period of relative quiescence lasting $800 \mathrm{ky}(1.90$ to $1.10 \mathrm{Ma})$ and only interrupted by the G.IV cycle.

\section{Acknowledgements}

This work was supported by the French Geological Survey (BRGM) and the DSM (CEA Saclay). The authors would like to thank Dr. B. Platevoet for helpful discussions and Dr. J.L. Joron for the sample irradiations carried out at the Pierre Süe Laboratory (CEA Saclay). LSCE contribution $n^{\circ} \mathrm{XXX}$.

\section{References}

Ablin D (1991) Analyse pollinique des dépôts lacustres de Ceyssac, Plio-Pléistocène du Velay (Massif central, France). Cahiers Micropaléontologie 1:21-38

Ablin D, Couthures J (1987) La stratigraphie des formations du vallon de Ceyssac, Plio- 
Pléistocène du Velay, Massif central français. C. R. Acad. Sci. Paris 305:1243-1247

Baubron JC, Cantagrel JM (1980) Les deux volcans des Monts-Dore (Massif Central français). C. R. Acad. Sci. Paris 290:1409-1412

Bellon H, Brousse R, Mervoyer B, Blais, S (1972). Age absolu du massif du Mont-Dore. C. R. Acad. Sci. Paris $290: 2740-2743$

Besson JC (1978) Les formations volcaniques du versant oriental du massif du Mont-Dore (Massif Central français), 1/25 000, Veyre-Monton 5-6, Ph.D Dissertation, University of Clermont Ferrand

Bernard B, Van Wyk de Vries, B, Leyrit H (2009) Distinguishing volcanic debris avalanche deposits from their reworked products: the Perrier sequence (French Massif Central). Bull. Volcanol 71:1056-1071. doi :10.1007/s00445-009-0285-7

Boule M (1892) Découverte d'un squelette d'Elephas meridionalis dans les cendres basaltiques du volcan de Senèze (Haute-Loire). C. R. Acad. Sci. Paris 115:624-626

Bout P (1933) Observations géologiques sur le plateau de perrier, la région de Malbattu et les terrasses d'Issoire. Bull Soc. Hist. Nat. d'Auvergne, 38 p.

Bout P, Marty P (1936) Flore Asterienne de Perrier. Ann. Musee hist. Nat. de Marseille 28:56

Brauer A, Wulf S, Mangili C, Moscariello A (2007) Tephrochronological dating of varved interglacial lake deposits from Pianico-Sellere (Southern Alps, Italy) to around $400 \mathrm{ka}$. J. Quat. Sci 22:85-96. doi: 10.1002/jqs.1014

Brousse R (1971) Magmatologie du volcanisme néogène et quaternaire du Massif Central in Symposium Géologie, géomorphologie et structure profonde du Massif Central français, Plein Air Service, Clermont-Ferrand, pp 377-478

Cantagrel JM, Baubron JC (1983) Chronologie K-Ar des éruptions dans le massif volcanique des Monts-Dore : implications volcanologiques. Géol. France 2: 123-142 
Cantagrel JM, Briot D (1990) Avalanches et coulées de débris : le Volcan du Guéry - Où est la caldera d'effondrement dans le massif des Monts Dore ? C. R. Acad. Sci. Paris 311: 219225

Cocherie A., Fanning M., Jezequel P., Robert M. (2009) LA-MC-ICPMS and SHRIMP U-Pb dating of complex zircons from Quaternary tephras from the French Massif Central: Magma residence time and geochemical implications. Geochimica et Cosmochimica Acta 73:1095-1108

Couthures J, Pastre JF (1983). Chronostratigraphie du Plio-Pléisotocène d'Auvergne et du Velay : Nouveaux apports des datations radiométriques et du paléomagnétisme. Bull. Ass. Française pour l'Etude du Quaternaire 2, 13:9-18

Defive E, Gauthier A, Pastre, JF (2005) L'évolution plio-quaternaire du Bassin du Puy (Massif central, France) : rythmes morphosédimentaires et volcanisme. Quaternaire 16: $177-190$

Duffell A (1999) Contribution géochronologique à la stratigraphie volcanique du Massif des Monts Dore par la méthode ${ }^{40} \mathrm{Ar} /{ }^{39} \mathrm{Ar}$. Masters dissertation, University of ClermontFerrand

Féraud G, Lo Bello, P, Hall CM, Cantagrel JM, York D, Bernat M (1990) Direct dating of Plio-Quaternary pumices by 40Ar/39Ar step-heating and single-grain laser fusion methods: the example of the Monts-Dore massif (Massif Central, France). J. Volcanol. Geotherm. Res 40:39-53. doi : 10.1016/0377-0273(90)90105-O

Girod M, Boullier R, Roche A, Weber F, Larqué P, Giot D, Guérin C, Bladier Y, Laurent, P, Bambier A (1979) Carte géologique de la France à 1/50 000. Le Puy. Service géologique national, BRGM, Orléans

Haug GH, Ganopolski A, Sigman, DM, Rosell-Mele A, Swann GEA, Tiedemann R, Jaccard SL, Bollmann J, Maslin MA, Leng, MJ, Eglinton G (2005) North Pacific seasonality and 
glaciation of North America, 2.7 million years ago. Nature 433:821-825. doi: 10.1038 /nature03332

Koppers AAP (2002) ArAr CALC - software for ${ }^{40} \mathrm{Ar} /{ }^{39} \mathrm{Ar}$ age calculations. Comp. Geosci 28:605-619. doi: 10.1016/S0098-3004(01)00095-4

Kuiper KF, Deino A, Hilgen FJ, Krijgsman W, Renne PR, Wijbrans JR (2008) Synchronizing rock clocks of Earth history. Science 320:500-504. doi: 10.1126/science.1154339

Leroy SAG, Arpe K, Mikolajewicz, U (2011) Vegetation context and climatic limits of the Early Pleistocene hominin dispersal in Europe. Quat. Sci. Rev 30:1448-1463. doi: 10.1016/j.quascirev.2010.01.017

Lisiecki LE, Raymo ME (2005) A Pliocene-Pleistocene stack of 57 globally distributed benthic delta O-18 records. Paleoceanography 20, PA1003 doi:10.1029/2004PA001071

Lisiecki LE, Raymo ME (2007) Plio-Pleistocene climate evolution: trends and transitions in glacial cycle dynamics. Quat. Sci. Rev 26:56-69. doi: 10.1016/j.quascirev.2006.09.005

Lo Bello P (1988). Géochronologie par la méthode 39Ar/40Ar de ponces quaternaries comtaminées. Exemple des ponces du Mont-Dore (Massif Central français). Utilisation d'un laser continu pour la datation de minéraux individuels. PhD dissertation, Université de Nice

Lo Bello P, Feraud G, Hall, CM, York D, Lavina P, Bernat M (1987) ${ }^{40}$ Ar $/{ }^{39}$ Ar step-heating and laser fusion dating of a Quaternary pumice from Neschers, Massif Central, France: The defeat of xenocrystic contamination. Chem. Geol. 66:61-71. doi: 10.1016/01689622(87)90029-7

Ménard JJ (1979) Contribution à l'étude pétrogénétique des nappes de ponces du massif volcanique du Mont-Dore (Massif Central français). PhD dissertation, Université de Paris 11 , Orsay

Morel JM (1987) Volcanologie du massif de l'Aiguiller (Monts Dore, Massif Central français) 
étude petrographique, dynamique, structurale et rhéologie des coulées de boue associées. $\mathrm{PhD}$ dissertation, University of Clermont-Ferrand

Mossand P (1983) Le volcanisme ante et syn-caldera des Monts Dore (Massif Central français). Implications géothermiques. PhD dissertation, University of Clermont-Ferrand.

Mossand P, Cantagrel JM, Vincent PM (1982) La caldera de Haute-Dordogne. Age et limites (Massif des Monts- Dore, France). Bull. Soc. Geol. Fr 24:727-738

Nomade S, Renne PR, Vogel N, Deino AL, Sharp WD, Becker TA, Jaouni AR, Mundil R (2005) Alder Creek sanidine (ACs-2): A Quaternary ${ }^{40} \mathrm{Ar} /{ }^{39} \mathrm{Ar}$ dating standard tied to the Cobb Mountain geomagnetic event. Chem. Geol. 218:315-338. doi: 10.1016/j.chemgeo.2005.01.005

Nomade S, Gauthier A, Guillou H, Pastre JF (2010) ${ }^{40} \mathrm{Ar} /{ }^{39} \mathrm{Ar}$ temporal framework for the Alleret maar lacustrine sequence (French Massif-Central): Volcanological and paleoclimatic implications. Quat. Geochronol 5:20-27. doi: 10.1016/j.quageo.2009.07.001

Nomade S, Scaillet S, Pastre JF, Nehlig P (2012) Pyroclastic chronology of the Sancy stratovolcano (Mont-Dore, French Massif Central): new high-precision ${ }^{40} \mathrm{Ar} /{ }^{39} \mathrm{Ar}$ constraints. J. Volcanol. Geotherm. Res. 225-226:1-12. doi: 10.1016/j.jvolgeores.2012.02.006

Nomade S, Pastre JF, Guillou H, Faure M, Guérin, G, Delson, E, Debard E, Voinchet P, Messager E (2013) ${ }^{40} \mathrm{Ar} /{ }^{39} \mathrm{Ar}$ constraints on some French landmark Late Pliocene to Early Pleistocene large mammalian paleofauna: paleoenvironmental and paleoecological implications. Quat. Geochronol In press doi: 10.1016/j.quageo.2012.12.006

Paquereau Lebti P, Thouret J-C, Wörner G, Fornari M (2006) Neogene and Quaternary ignimbrites in the area of Arequipa Southern Peru: Stratigraphical and petrological correlations. J. Volcanol. Geotherm. Res. 154:251-275. doi: 10.1016/j.jvolgeores.2006.02.014 
Pastre JF (1987) Les formations plio-quaternaires du bassin de l'Allier et le volcanisme régional (Massif Central, France). Rapports géodynamiques, corrélations téphrochronologiques, implications. PhD dissertation, University of Paris VI

Pastre JF (2004) The Perrier Plateau: a Plio-pleistocene long fluvial record in the river Allier Basin, Massif Central, France. Quaternaire 15:87-102

Pastre JF, Cantagrel JM (2001) Téphrostratigraphie du Mont Dore (Massif Central, France). Quaternaire 12:249-267

Pastre JF, Gauthier A, Nomade S. Orth P, Andrieu A, Goupille F, Guillou H, Kunesch S, Scaillet S, Renne PR (2007) The Alleret maar (Massif Central, France): a new lacustrine sequence of the early Middle Pleistocene in Western Europe. C. R. Geosci 339:987-997. doi: 10.1016/j.crte.2007.09.019

Raymo ME, Lisiecki LE, Nisancioglu KH (2006) Plio-Pleistocene Ice Volume, Antarctic Climate, and the Global $\delta^{18}$ O Record. Science 313:492-495. doi: 10.1126/science. 1123296

Renne, P. R., C.Swisher, C. C., III, Deino, A. L., Karner, D. B., Owens, T., and DePaolo, D. J., (1998) Intercalibration of standards, absolute ages and uncertainties in ${ }^{40} \mathrm{Ar} /{ }^{39} \mathrm{Ar}$ dating: Chemical Geol. 145:117-152.

Renne PR, Deino AL, Hames WE, Heizler MT, Hemming SR, Hodges KV, Koppers AAP, Mark DF, Morgan LE, Phillips D, Singer BS, Turrin BD, Villa IM, Villeneuve M, Wijbrans JR (2009) Data reporting norms for ${ }^{40} \mathrm{Ar} /{ }^{39} \mathrm{Ar}$ geochronology, Quat. Geochronol $4: 346-352$.

Renne PR, Mundil R, Balco G, Min K, Ludwig KR (2011) Response to the comment by W.H. Schwarz et al. on "Joint determination of ${ }^{40} \mathrm{~K}$ decay constants and ${ }^{40} \mathrm{Ar}^{*} /{ }^{40} \mathrm{~K}$ for the Fish Canyon sanidine standard, and improved accuracy for ${ }^{40} \mathrm{Ar} /{ }^{39} \mathrm{Ar}$ geochronology" by P.R. Renne et al. (2010), Geochim. Cosmochim. Acta 75:5097-5100. doi: 10.1016/j.gca.2011.06.021 
Roger S, Féraud G, de Beaulieu JL, Thouveny N, Coulon C, Cocheme JJ, Andrieu V, Williams $\mathrm{T}$ (1999) ${ }^{40} \mathrm{Ar} /{ }^{39} \mathrm{Ar}$ dating on tephra of the Velay maars (France); implications for the late Pleistocene proxy-climatic record. Earth Planet. Sci. Lett 170:287-299. doi: $10.1016 / \mathrm{S} 0012-821 \mathrm{X}(99) 00242-3$

Roulleau E, Pinti DL, Rouchon V, Quidelleur X, Gillot PY (2009) Tephro-chronostratigraphy of the lacustrine interglacial record of Piànico, Italian Southern Alps: Identifying the volcanic sources using radiogenic isotopes and trace elements. Quat. Int 204:31-43. doi. 10.1016/j.quaint.2009.01.006

Schmitz MD (2012) Radiogenic isotope geochronology. In: Gradstein FM, Ogg JG. Schmitz, MD Ogg G (ed.) The Geological Time Scale 2012. Elsevier, pp 115-125

Steiger RH, Jäger E (1977) Subcommission on geochronology: convention on the use of decay constants in geo- and cosmochronology. Earth Planet. Sci. Lett. 36: 359-362. doi: $10.1016 / 0012-821 X(77) 90060-7$

Vincent PM (1979) Un repère chronologique dans la caldera des Monts-Dore (Massif Central français) : les pyroclastites du dôme de la Gacherie. C. R. Acad. Sci. Paris 289:1009-1012. Vincent PM (1980) Volcanisme et chambres magmatiques : l'exemple des Monts Dore. Mém. hors-série de la Soc. Géol. France 10:71-85 


\section{Figure and table captions}

Table 1: List of available ${ }^{40} \mathrm{Ar} /{ }^{39} \mathrm{Ar}$ ages for the Mont-Dore Massif. Bold font corresponds to ages from the present work.

Fig. 1 a) Simplified geological map of the Cantal and Mont-Dore massifs; b) The DevèsVelay and Ardèche valley volcanic fields showing the location of distal deposits from the Mont-Dore Massif and previously dated in Roger et al. (1999); Pastre et al. (2007); Nomade et al. (2010, 2012, 2013). Per: Perrier Plateau; Sen: Senèze maar; All: Alleret maar; Chil: Chilhac site; Bou: Bouchet Lake; Ceys: Ceyssac

Fig. 2 Geological map of the Mont-Dore Massif and location of the ${ }^{40} \mathrm{Ar} /{ }^{39}$ Ar-dated sample sites

Fig. 3 a) Geological map of the Perrier Plateau and b) cross-sections showing sample locations and fauna and flora sites; c) Geological map of the Velay region and Ceyssac section

Fig. 4 Age probability distribution spectra, individual age analyses ( $1 \sigma$ analytical uncertainties) and corresponding inverse isochron plots for the Bourboule-Vendeix streamsection samples. Black and white boxes are juvenile and inherited crystals, respectively.

Fig. 5 Age probability distribution spectra, individual age analyses ( $1 \sigma$ analytical uncertainties) and corresponding inverse isochron plots for the Pessy-Pregnoux and Guéry proximal pyroclastic units . Black and white boxes are juvenile and inherited crystals, respectively.

Fig. 6 Age probability distribution spectra, individual age analyses ( $1 \sigma$ analytical uncertainties) and corresponding inverse isochron plots for the Perrier Plateau samples. Black and white boxes are juvenile and inherited crystals, respectively. 
Fig. $7{ }^{40} \mathrm{Ar} /{ }^{39} \mathrm{Ar}$ age spectrum (left) and inverse isochron (right) for the Ceyssac tephra layer ( $1 \sigma$ analytical uncertainties)

Fig. 8 Chronology of the pyroclastic units of the Guéry stratovolcano. Individual mean ages as well as individual single-crystal ages were recalculated according to the Kuiper et al. (2008) calibration. Grey circles and squares correspond to the ages from this study and black ones to previous studies. GN and PA correspond to the Grande-Nappe and the Perrier debris Avalanches, respectively

Fig. 9 Synthetic log for the pumice flows on the left bank of the Dordogne River (modified from Pastre and Cantagrel, 2001) and new log proposed for the same area. The upper part of both logs (Sancy stratovolcano) is based on the work of Nomade et al. (2012)

Fig. 10 Tephrostratigraphy of the Mont-Dore Massif between 3.1 Ma and 290 ka. Individual mean pyroclastic ages as well as individual single-crystal ages were recalculated according to the Kuiper et al. (2008) calibration. 


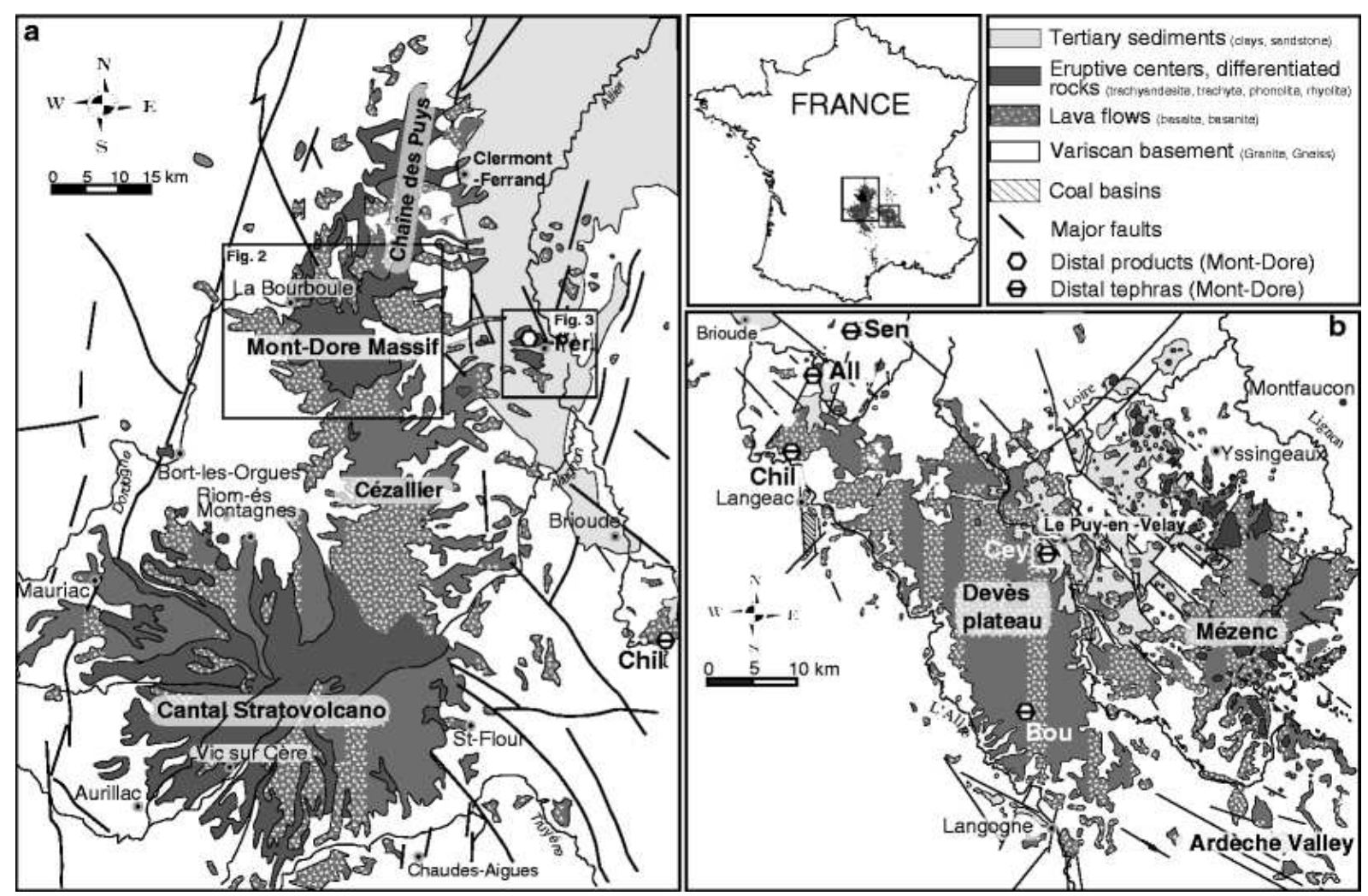




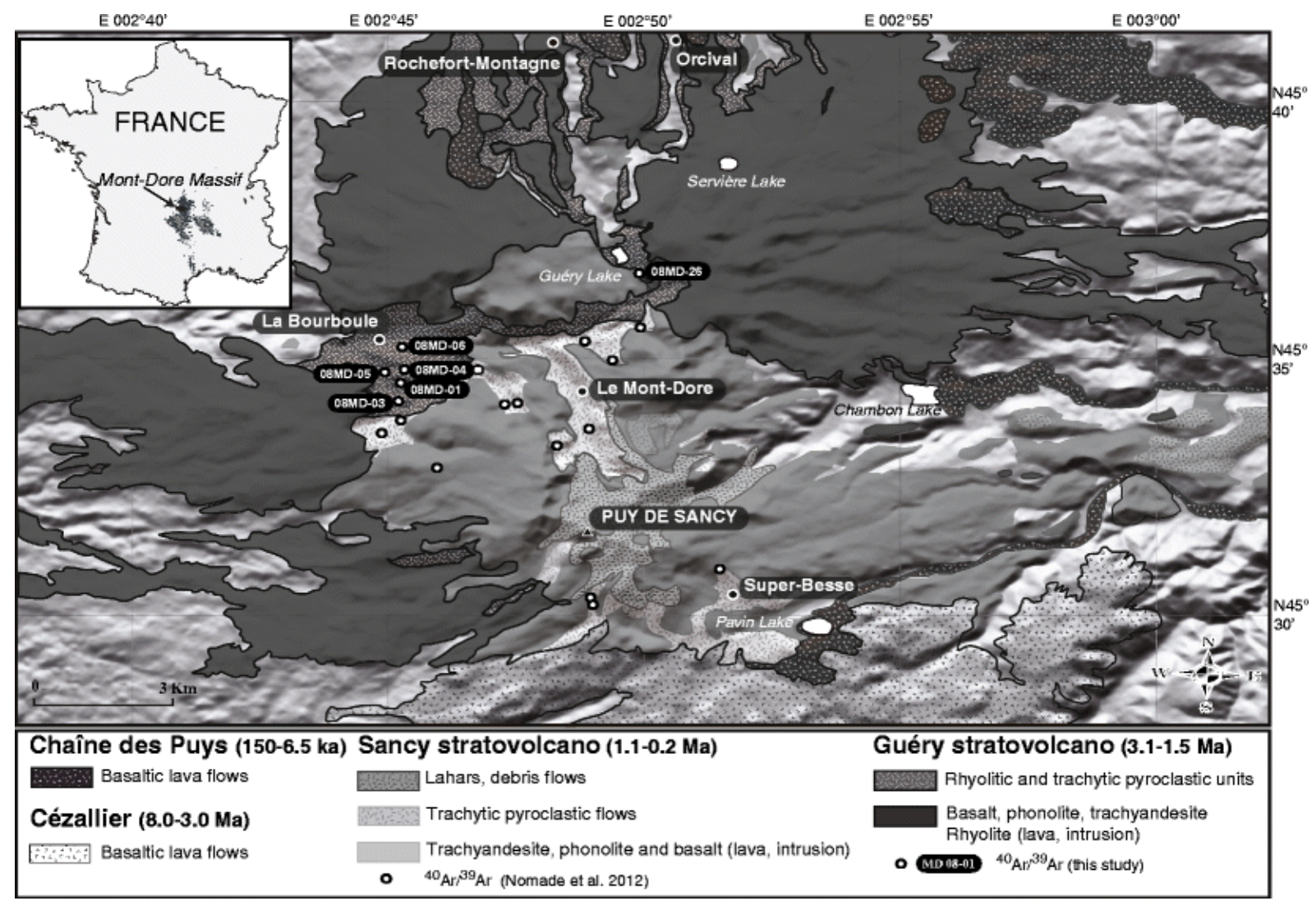



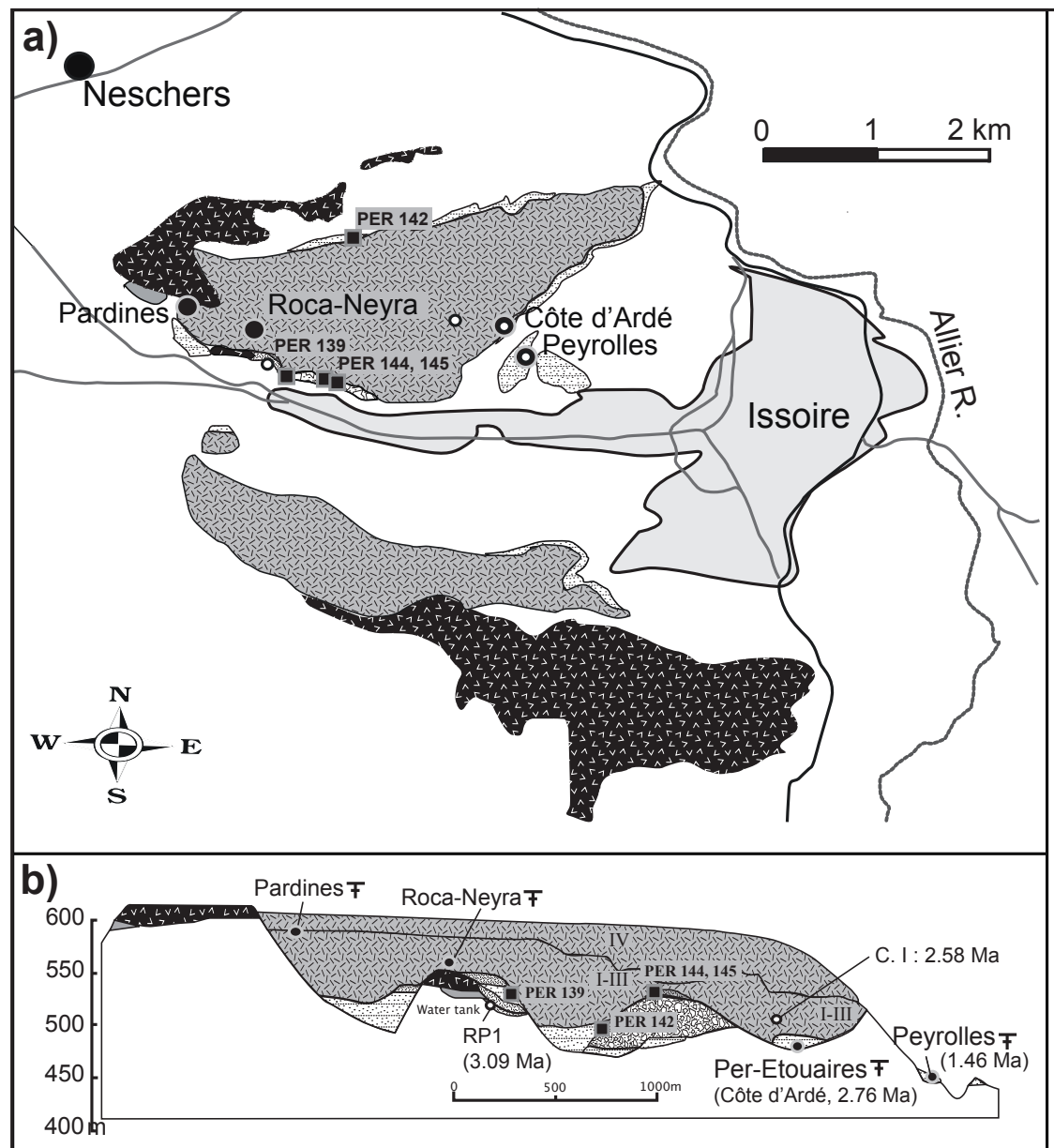

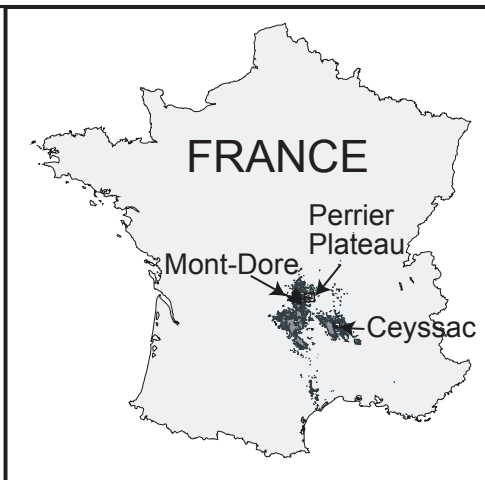

Pliocene, Early-Pleistocene

स्स: Perrier avalanches ( $\mathrm{Cl}$ to IV)

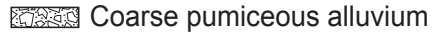

Trachytic ignimbrite, plinian falls.

Terrace with interbedded pumices

Basanite and doleritic basalts

Miocene-Oligocene

$\square$ Alluvium

$\square$ Marls and Limestone

River / Road, Highway

- Fauna and $40 \mathrm{Ar} / 39 \mathrm{Ar}$ age (Nomade et al. 2013)

- ${ }^{40} \mathrm{Ar} /{ }^{39} \mathrm{Ar}$ sample (Nomade et al. 2013)

口 ${ }^{40} \mathrm{Ar} /{ }^{39} \mathrm{Ar}$ sample (this study)
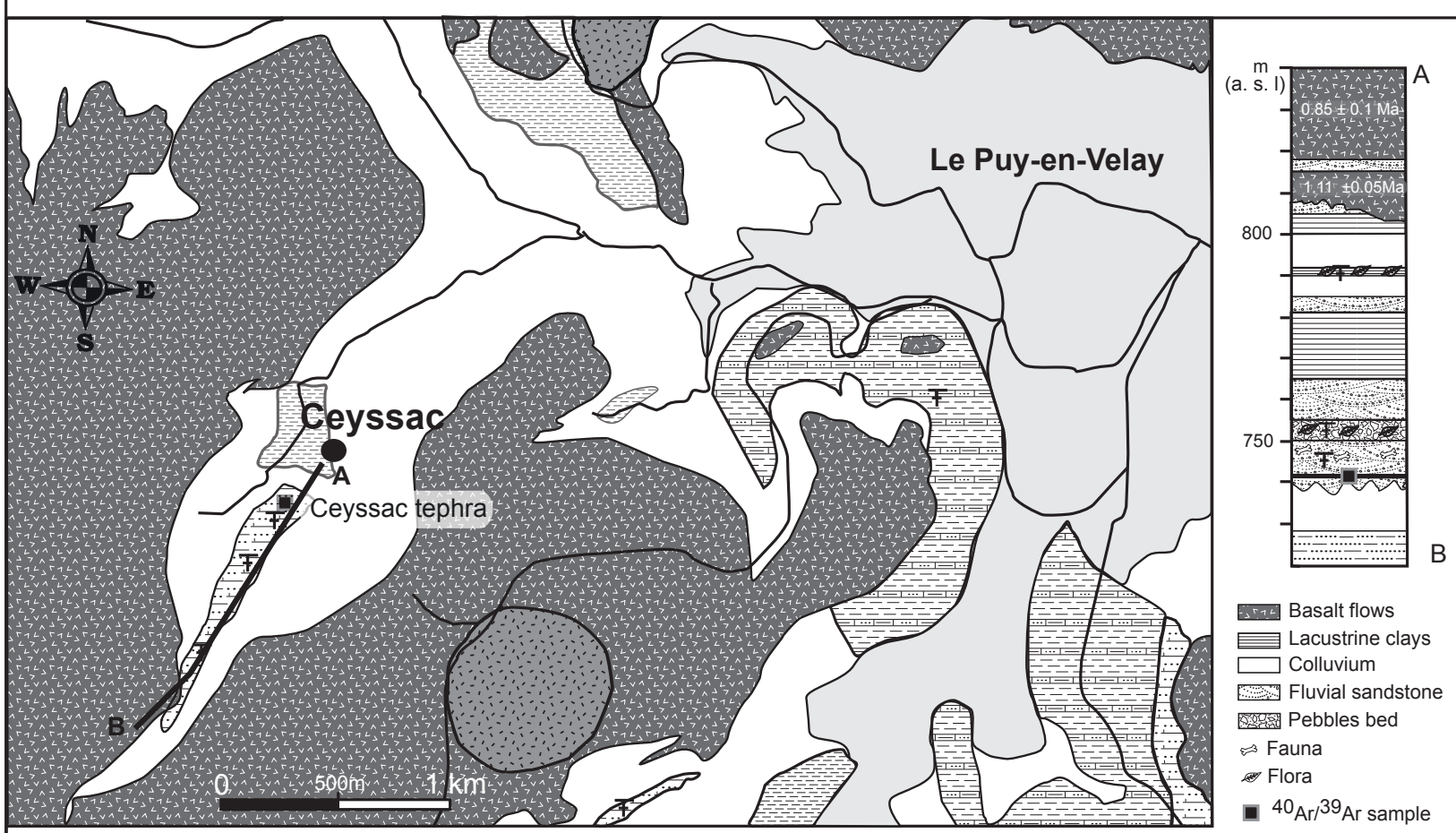

$\square$ Undifferentiated recent colluvium

Middle to Early Pleistocene volcanism

Strombolian cones, tuffs

Alkaline basalt and hawaite

Early to Middle Pleistocene Eocene-Oligocene

Sandstone, clays

$\mp$ Fauna and flora sites Clays

c)

\section{Fig. 3}


Figure 4
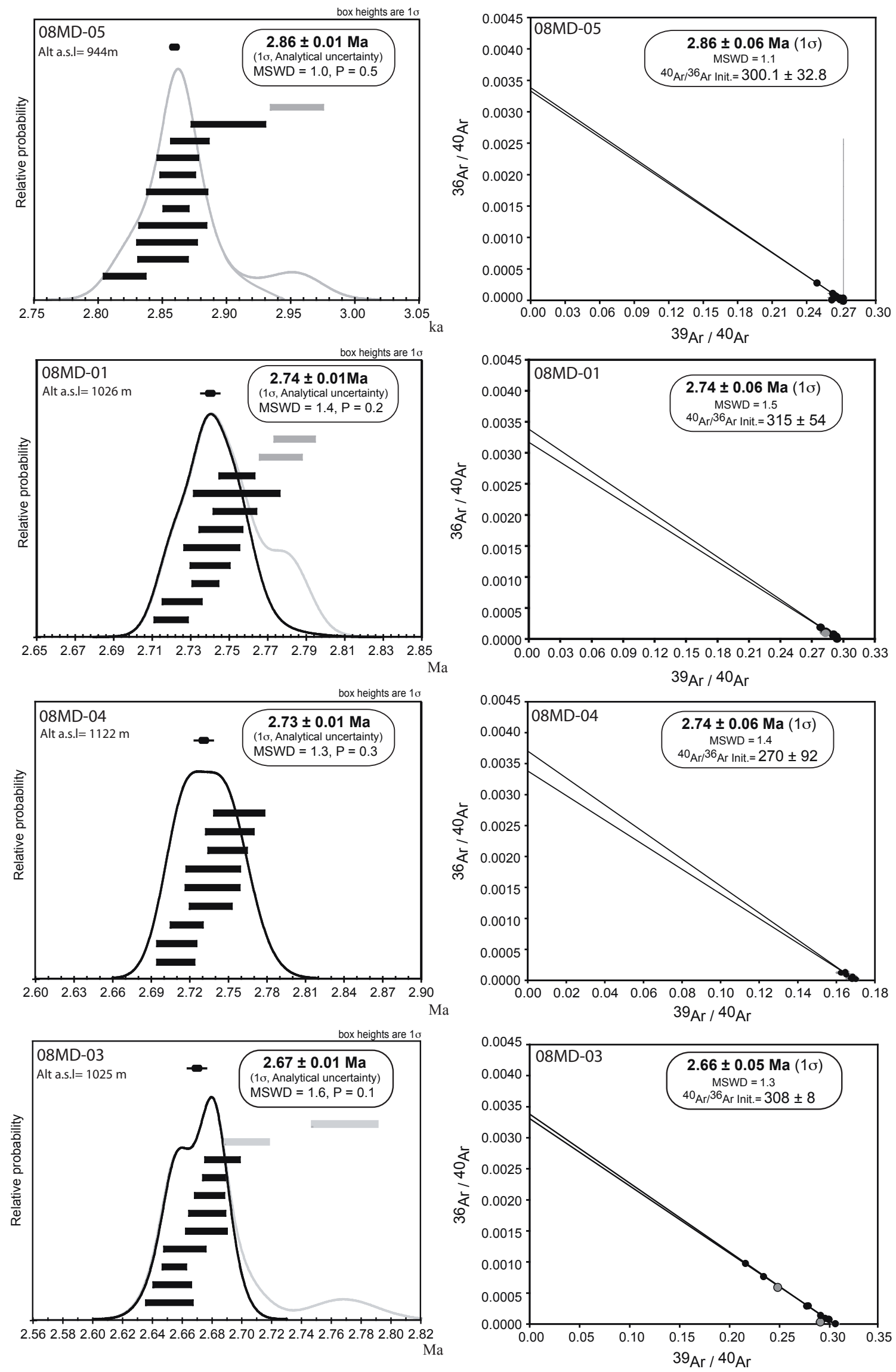

Fig. 4 
Figure 5
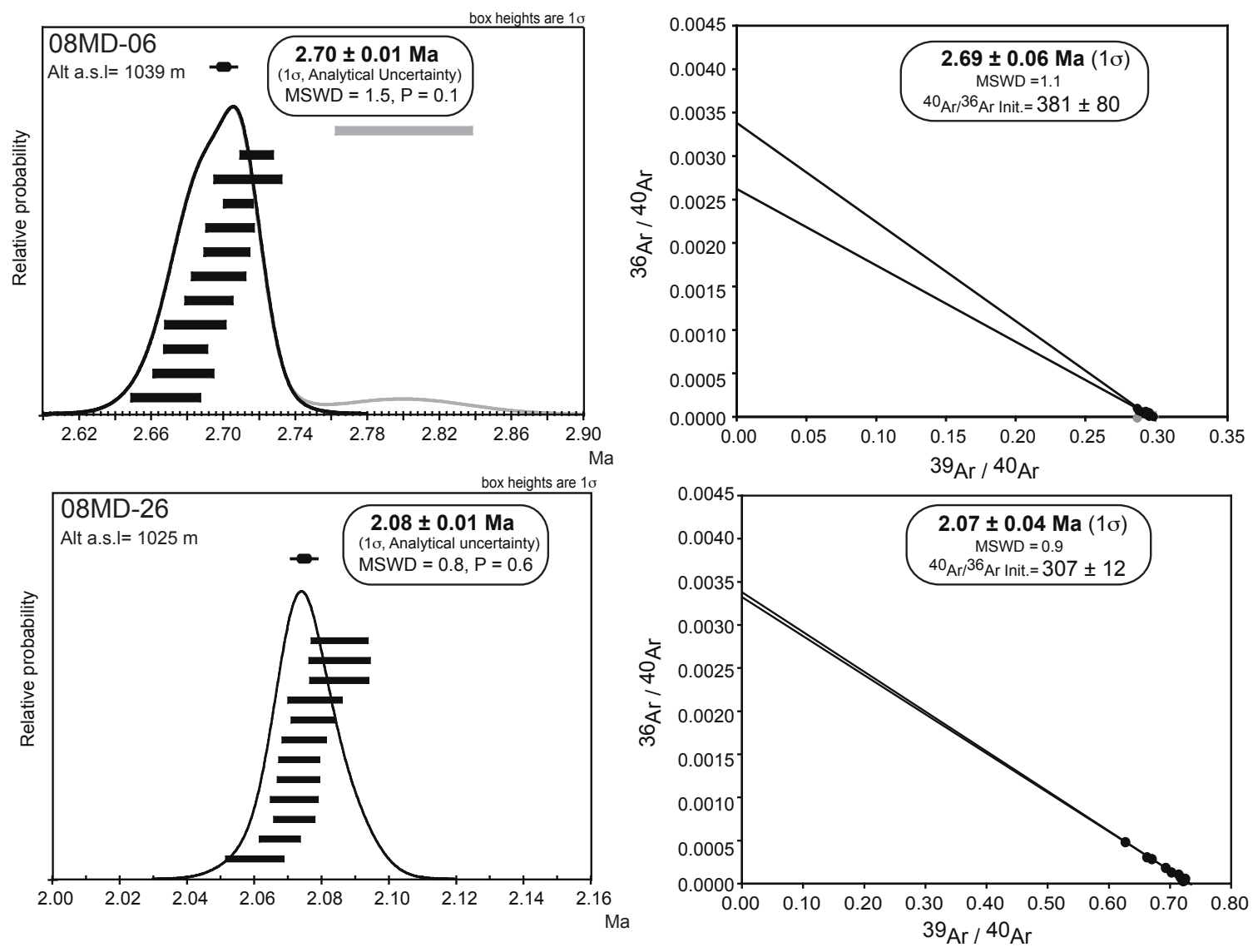

Fig. 5 

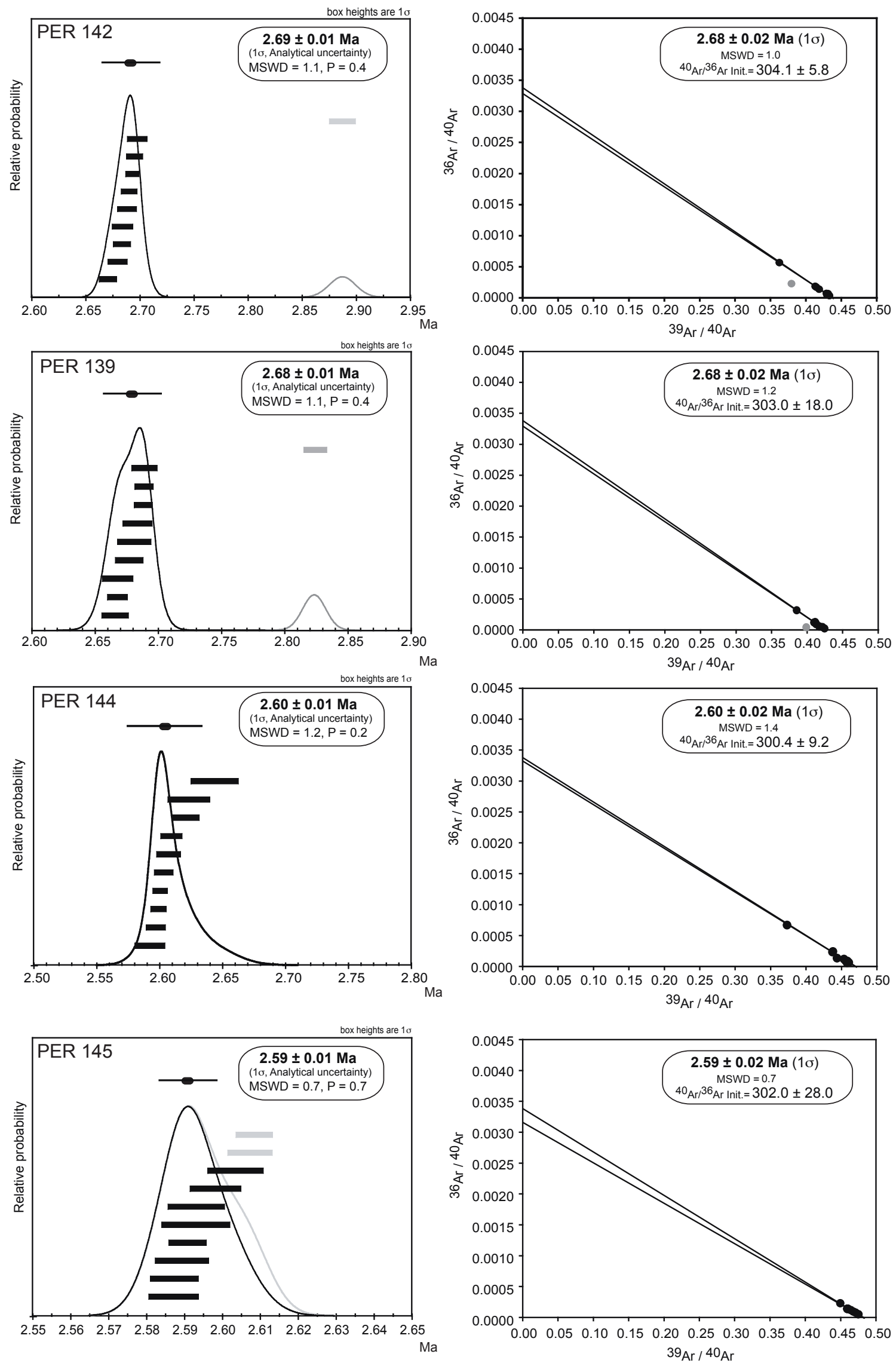

Fig. 6 
Figure 7
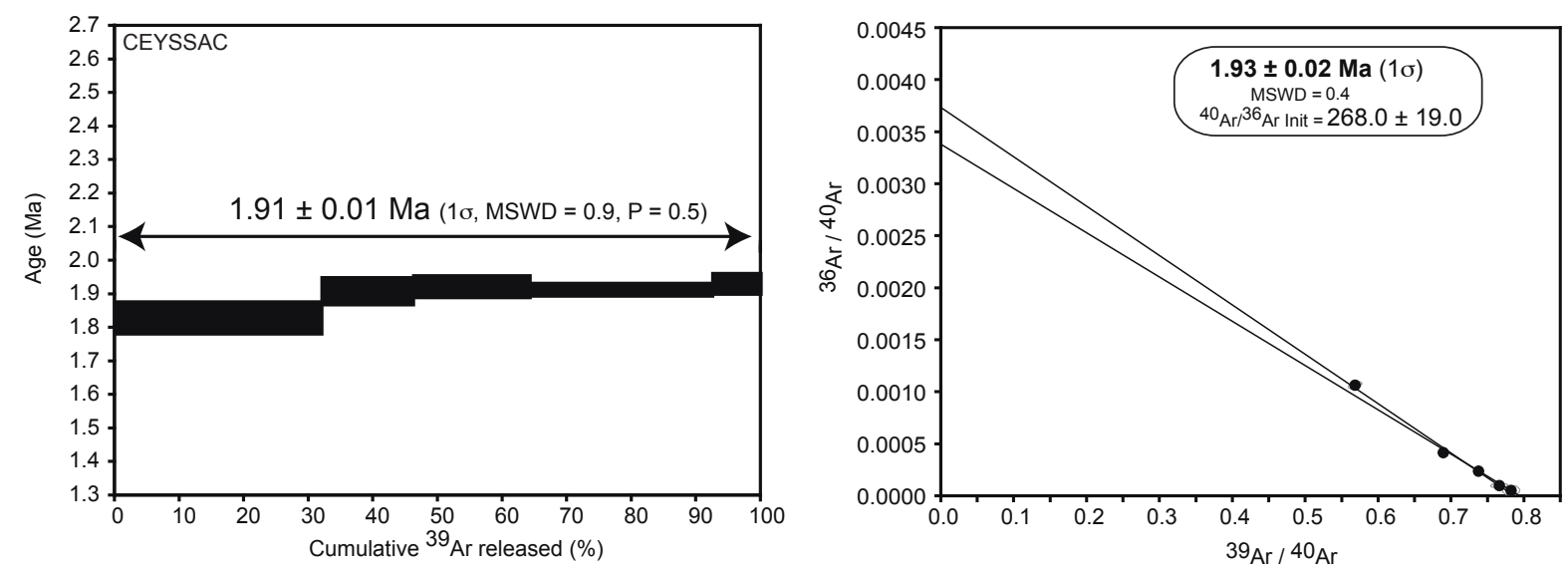

Fig. 7 
Figure 8

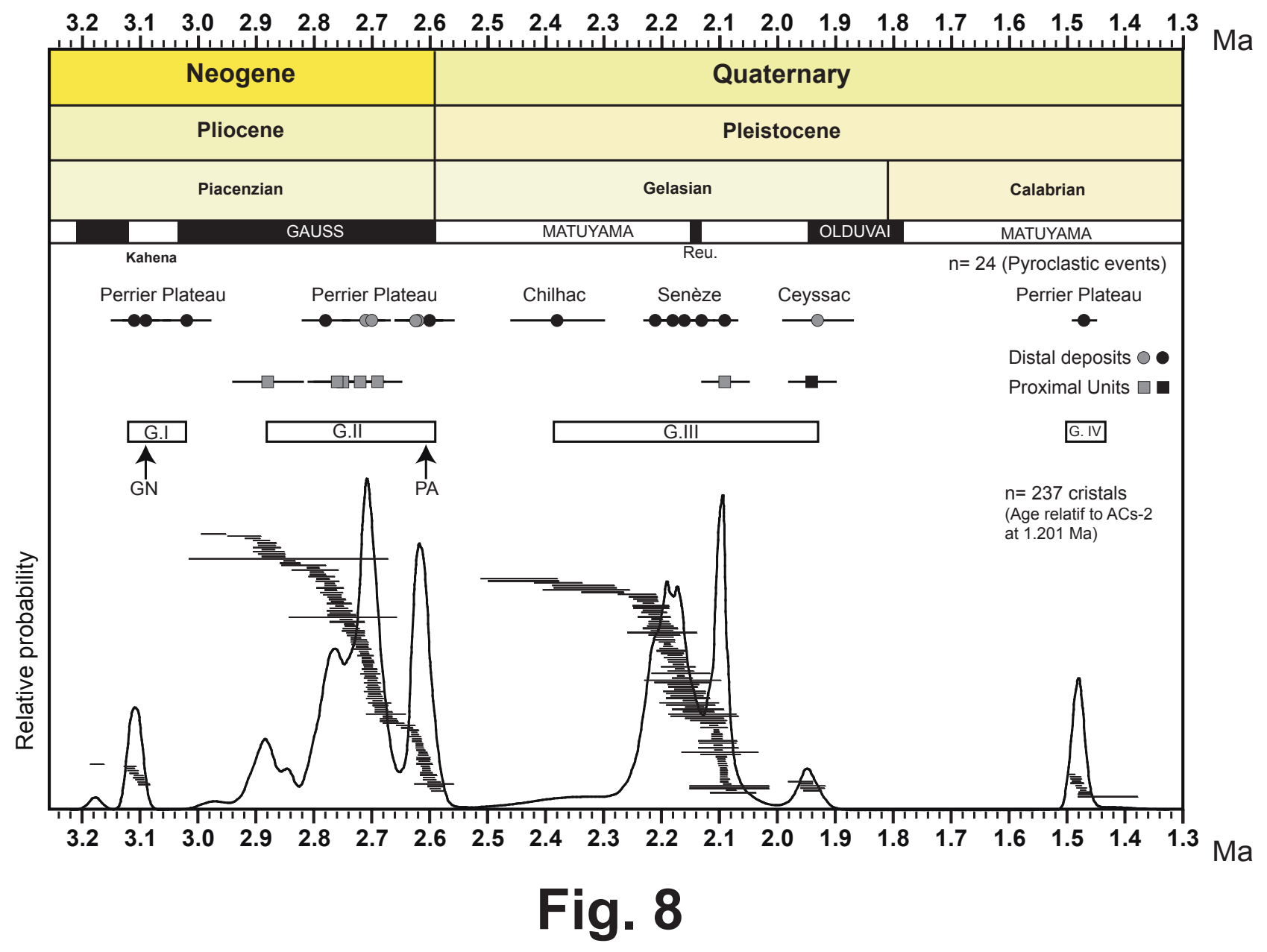


Figure 9

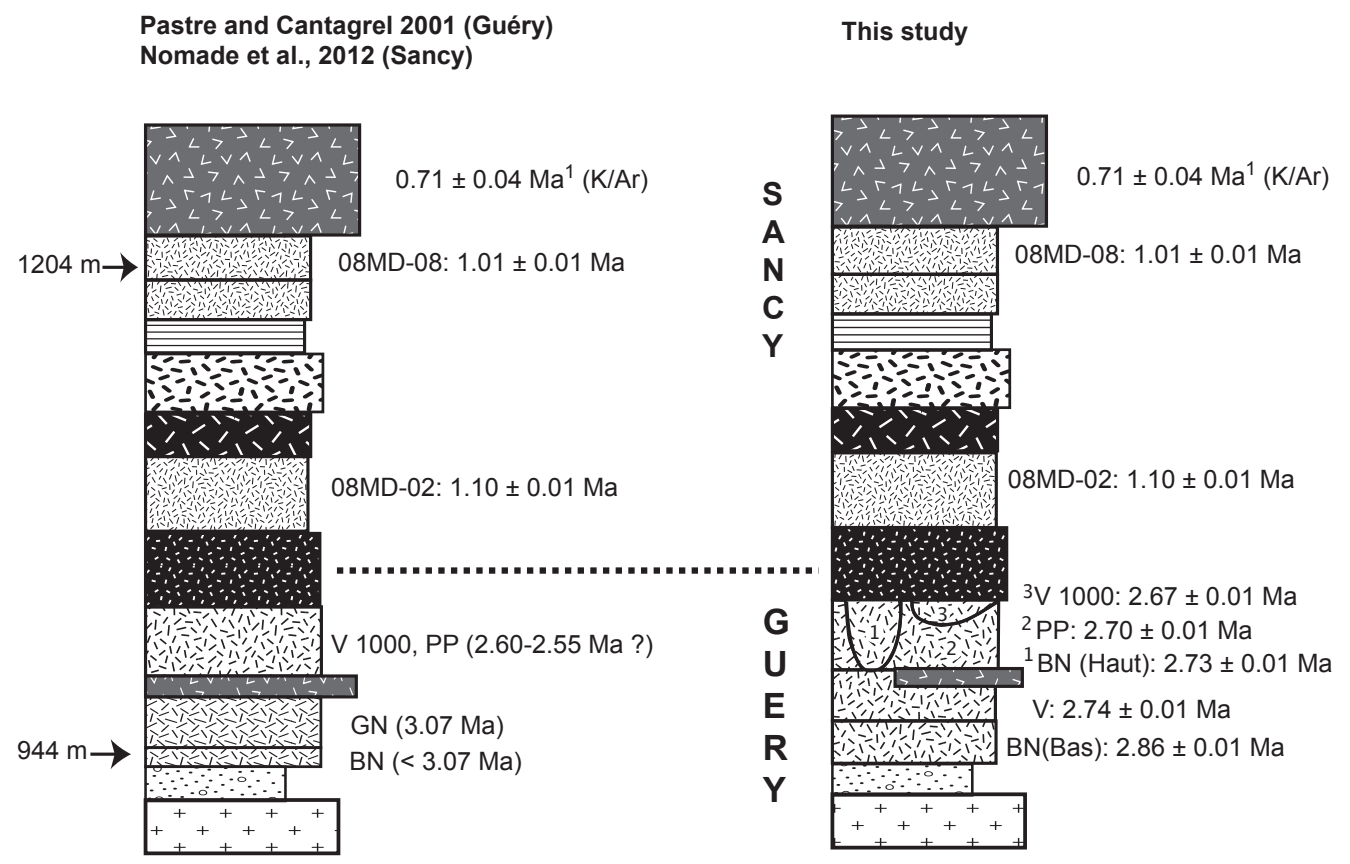

Legend

E目 Laminated sandstone

$F=:-3$ Bloc and ash-falls

$\therefore \because$ Ash-flow with dark-micas

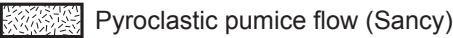

Avalanche with tuffites and blocs

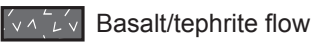

运谓 Pyroclastic pumice ash flow (Guéry)

$\therefore$ Sandstone, reworked rhyolitic material

${ }_{+}^{+}$Granitic basement

Fig. 9 
Figure 10

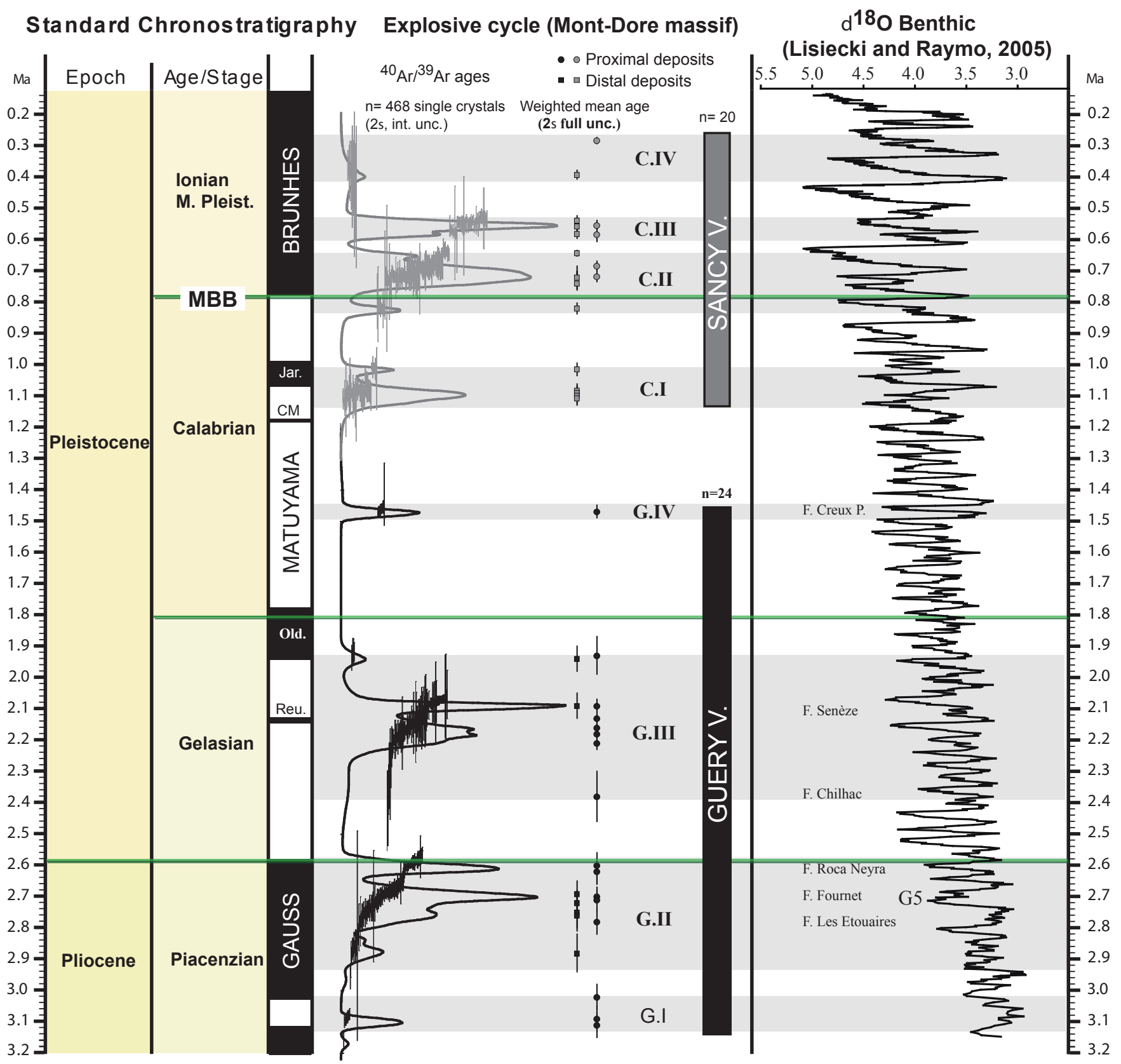

Fig. 10 
Table 1

SANCY STRATOVOLCANO

\begin{tabular}{|c|c|c|c|c|c|c|c|c|c|c|c|c|}
\hline $\begin{array}{l}\text { Unit, given name } \\
\text { * Distal deposits }\end{array}$ & Ref. & $\begin{array}{c}\text { Prev. Study } \\
\text { (ACs-2, 1.193 Ma) }\end{array}$ & $\begin{array}{l}\text { Sample } \\
\text { Name }\end{array}$ & 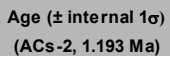 & (ACs-2, 1.201 Ma) & $\begin{array}{c} \pm(1 \mathbf{s}) \\
\text { external }\end{array}$ & MSWD & $\mathbf{P}$ & $\begin{array}{l}\text { Isochrone Age } \pm 1 \sigma \\
\text { (ACs-2, 1.194 Ma) }\end{array}$ & (ACs-2, 1.201Ma) & MSWL & ${ }^{0} \mathrm{Ar}^{36} \mathrm{Ar}_{\mathrm{rint}}$ \\
\hline Bouchet tephra* & 1 & $0.284 \pm 0.005 \mathrm{Ma}$ & & & $0.286 \pm 0.005 \mathrm{Ma}$ & $0.006 \mathrm{Ma}$ & 0.6 & 0.9 & $0.295 \pm 0.011 \mathrm{Ma}$ & $0.297 \pm 0.011 \mathrm{Ma}$ & 0.7 & $298 \pm 25$ \\
\hline Barbier & 2 & & 08MD-16 & $0.392 \pm 0.006 \mathrm{Ma}$ & $0.395 \pm 0.006 \mathrm{Ma}$ & $0.007 \mathrm{Ma}$ & 1.7 & 0.05 & $0.391 \pm 0.007 \mathrm{Ma}$ & $0.394 \pm 0.007 \mathrm{Ma}$ & 1.6 & $297 \pm 2$ \\
\hline Queureuilh (ligh) & 2 & & 08MD15bis & $0.537 \pm 0.004 \mathrm{Ma}$ & $0.540 \pm 0.004 \mathrm{Ma}$ & $0.007 \mathrm{Ma}$ & 1.2 & 0.3 & $0.536 \pm 0.007 \mathrm{Ma}$ & $0.539 \pm 0.007 \mathrm{Ma}$ & 1.3 & $298 \pm 3$ \\
\hline Alleret" ${ }^{*}$ & 3 & & & $0.554 \pm 0.002 \mathrm{Ma}$ & $0.557 \pm 0.002 \mathrm{Ma}$ & $0.008 \mathrm{Ma}$ & 0.7 & 0.9 & $0.551 \pm 0.003 \mathrm{Ma}$ & $0.555 \pm 0.003 \mathrm{Ma}$ & 0.6 & $300 \pm 3$ \\
\hline Rivaux & 2 & & 08MD-14 & $0.555 \pm 0.003 \mathrm{Ma}$ & $0.559 \pm 0.003 \mathrm{Ma}$ & $0.008 \mathrm{Ma}$ & 0.7 & 0.7 & $0.554 \pm 0.008 \mathrm{Ma}$ & $0.558 \pm 0.008 \mathrm{Ma}$ & 0.8 & $297 \pm 2$ \\
\hline Neschers* ${ }^{*}$ & 4 & $0.584 \pm 0.020 \mathrm{Ma}$ & NEST & & $0.588 \pm 0.020 \mathrm{Ma}$ & $0.020 \mathrm{Ma}$ & 0.8 & 0.5 & & & NA & NA \\
\hline Egravat & 2 & & 08MD-13 & $0.578 \pm 0.003 \mathrm{Ma}$ & $0.582 \pm 0.003 \mathrm{Ma}$ & $0.008 \mathrm{Ma}$ & 1.7 & 0.1 & $0.580 \pm 0.008 \mathrm{Ma}$ & $0.584 \pm 0.008 \mathrm{Ma}$ & 0. & $292 \pm 3$ \\
\hline Queureuilh (low) & 2 & & 08MD-12 & $0.642 \pm 0.004 \mathrm{Ma}$ & $0.646 \pm 0.004 \mathrm{Ma}$ & $0.009 \mathrm{Ma}$ & 1.2 & 0.7 & $0.645 \pm 0.009 \mathrm{Ma}$ & $0.649 \pm 0.009 \mathrm{Ma}$ & 1.3 & $285 \pm 21$ \\
\hline Alleret" & 5 & & $\mathrm{~S} 223$ & $0.683 \pm 0.002 \mathrm{Ma}$ & $0.687 \pm 0.002 \mathrm{Ma}$ & $0.008 \mathrm{Ma}$ & 1.2 & 0.3 & $0.689 \pm 0.010 \mathrm{Ma}$ & $0.693 \pm 0.010 \mathrm{Ma}$ & 0.9 & $268 \pm 10$ \\
\hline Alleret $^{*}$ & 5 & & s086 & $0.713 \pm 0.003 \mathrm{Ma}$ & $0.718 \pm 0.003 \mathrm{Ma}$ & $0.009 \mathrm{Ma}$ & 0.7 & 0.8 & $0.711 \pm 0.009 \mathrm{Ma}$ & $0.716 \pm 0.009 \mathrm{Ma}$ & 0.8 & $01 \pm 6$ \\
\hline Alleret ${ }^{*}$ & 5 & & s036 & $0.717 \pm 0.003 \mathrm{Ma}$ & $0.722 \pm 0.003 \mathrm{Ma}$ & $0.009 \mathrm{Ma}$ & 1.8 & 0.05 & $0.721 \pm 0.012 \mathrm{Ma}$ & $0.726 \pm 0.012 \mathrm{Ma}$ & 3.1 & $288 \pm 7$ \\
\hline Rioubes & 6 & & Super-Besse & $0.718 \pm 0.018 \mathrm{Ma}$ & $0.723 \pm 0.018 \mathrm{Ma}$ & $0.018 \mathrm{Ma}$ & 0.1 & 0.9 & & & NA & NA \\
\hline La-Biche & 2 & & 08MD-19 & $0.719 \pm 0.006 \mathrm{Ma}$ & $0.724 \pm 0.006 \mathrm{Ma}$ & $0.010 \mathrm{Ma}$ & 1.7 & 0.1 & $0.720 \pm 0.010 \mathrm{Ma}$ & $0.725 \pm 0.010 \mathrm{Ma}$ & 2.0 & $301 \pm 7$ \\
\hline Chareire (high) & 2 & & 08MD-18 & $0.736 \pm 0.004 \mathrm{Ma}$ & $0.741 \pm 0.004 \mathrm{Ma}$ & $0.010 \mathrm{Ma}$ & 1.5 & 0.2 & $0.740 \pm 0.010 \mathrm{Ma}$ & $0.745 \pm 0.010 \mathrm{Ma}$ & 1.0 & $261 \pm 17$ \\
\hline Chareire (low) & 2 & & 08MD-17 & $0.817 \pm 0.004 \mathrm{Ma}$ & $0.822 \pm 0.004 \mathrm{Ma}$ & $0.011 \mathrm{Ma}$ & 1.5 & 0.2 & $0.818 \pm 0.011 \mathrm{Ma}$ & $0.823 \pm 0.011 \mathrm{Ma}$ & 1.7 & $295 \pm 2$ \\
\hline Bois Latour & 2 & & 08MD-08 & $1.010 \pm 0.002 \mathrm{Ma}$ & $1.016 \pm 0.002 \mathrm{Ma}$ & $0.010 \mathrm{Ma}$ & 1.7 & 0.1 & $1.013 \pm 0.012 \mathrm{Ma}$ & $1.019 \pm 0.012 \mathrm{Ma}$ & 0.8 & $19 \pm 86$ \\
\hline Vernière & 2 & & 08MD-10 & $1.078 \pm 0.002 \mathrm{Ma}$ & $1.085 \pm 0.002 \mathrm{Ma}$ & $0.011 \mathrm{Ma}$ & 1.7 & 0.1 & $1.068 \pm 0.016 \mathrm{Ma}$ & $1.075 \pm 0.016 \mathrm{Ma}$ & 1.7 & $37 \pm 39$ \\
\hline Cliergue & 2 & & 08MD-11 & $1.085 \pm 0.002 \mathrm{Ma}$ & $1.092 \pm 0.002 \mathrm{Ma}$ & $0.011 \mathrm{Ma}$ & 1.6 & 0.1 & 1.083 & $1.09 c$ & 0.8 & $05 \pm 5$ \\
\hline Bozat, la Reine & 2 & & 08MD-09 & $1.095 \pm 0.003 \mathrm{Ma}$ & $1.102 \pm 0.003 \mathrm{Ma}$ & $0.011 \mathrm{Ma}$ & 1.7 & 0.1 & $1.106 \pm 0.013 \mathrm{Ma}$ & $1.113 \pm 0.013 \mathrm{Ma}$ & 0.8 & $296 \pm 2$ \\
\hline Vendeix & 2 & & 08MD-02 & $1.101 \pm 0.003 \mathrm{Ma}$ & $1.109 \pm 0.003 \mathrm{Ma}$ & $0.011 \mathrm{Ma}$ & 1.3 & 0.3 & $1.099 \pm 0.012 \mathrm{Ma}$ & 1. $106 \pm 0.012 \mathrm{Ma}$ & 1.1 & $303 \pm 5$ \\
\hline UERY STRA' & & & & & & & & & & & & \\
\hline $\begin{array}{l}\text { Unit, given name } \\
{ }^{*} \text { Distal de posits }\end{array}$ & Ref. & Prev. Study & Sample & Age ( \pm internal 1s) & & $\pm(1 \sigma)$ & MSWD & $\mathbf{P}$ & Isochrone Age $\pm 1 \sigma$ & & MSWL & $\mathrm{rr}^{36} \mathrm{Ar}_{\mathrm{rin}} \pm$ \\
\hline $\begin{array}{l}\text { Distal de pos its } \\
\text { Creux de peyrolles* }\end{array}$ & 8 & $\begin{array}{r}\text { (ACs-2, 1.193 M } \\
1.42 \pm 0.1 \mathrm{Ma}\end{array}$ & PER 07 & $\begin{array}{c}(\text { ACs-2, } 1.193 \mathrm{Ma}) \\
1.46 \pm 0.01 \mathrm{Ma}\end{array}$ & $\begin{array}{c}\text { (ACs-2, } 1.201 \mathrm{Ma} \text { ) } \\
1.47 \pm 0.01 \mathrm{Ma}\end{array}$ & $\begin{array}{c}\text { external } \\
0.01 \mathrm{Ma}\end{array}$ & & $0 ?$ & $\begin{array}{c}\text { (ACs-2, 1.194 Ma) } \\
1.46 \pm 0.01 \mathrm{Ma}\end{array}$ & $\begin{array}{c}\text { ACs-2, } 1.201 \mathrm{Ma}) \\
1.47 \pm 0.01 \mathrm{Ma}\end{array}$ & & $296+4$ \\
\hline Ceyssac * & & & CEY. & $1.92 \pm 0.01 \mathrm{Ma}$ & $1.93 \pm 0.01 \mathrm{Ma}$ & $0.02 \mathrm{Ma}$ & $\begin{array}{l}1.3 \\
0.9\end{array}$ & & $1.93 \pm 0.03 \mathrm{Ma}$ & $1.94 \pm 0.03 \mathrm{Ma}$ & $\begin{array}{l}1.4 \\
\mathbf{0 . 4}\end{array}$ & $\begin{array}{l}296 \pm 4 \\
268 \pm 19\end{array}$ \\
\hline Morangie & 6 & $1.93 \pm 0.02 \mathrm{Ma}$ & La Morangie & & $1.94 \pm 0.02 \mathrm{Ma}$ & $0.02 \mathrm{Ma}$ & 0.2 & 0.9 & NA & NA & NA & N/A \\
\hline Guéry & & $2.04 \pm 0.06 \mathrm{Ma}$ & 08MD-26 & $2.08 \pm 0.01 \mathrm{Ma}$ & $2.09 \pm 0.01 \mathrm{Ma}$ & $0.02 \mathrm{Ma}$ & 0.8 & 0.6 & $2.07 \pm 0.02 \mathrm{Ma}$ & $2.08 \pm 0.02 \mathrm{Ma}$ & 0.9 & $301 \pm 6$ \\
\hline Senèze $56^{*}$ & 7 & & SEN 56 & $2.08 \pm 0.01 \mathrm{Ma}$ & $2.09 \pm 0.01 \mathrm{Ma}$ & $0.01 \mathrm{Ma}$ & 1.4 & 0.2 & $2.08 \pm 0.01 \mathrm{Ma}$ & $2.09 \pm 0.01 \mathrm{Ma}$ & 0.8 & $292 \pm 8$ \\
\hline Senèze $1^{*}$ & 7 & & SEN 1 & $2.12 \pm 0.01 \mathrm{Ma}$ & $2.13 \pm 0.01 \mathrm{Ma}$ & $0.01 \mathrm{Ma}$ & 1.0 & 0.5 & $2.10 \pm 0.02 \mathrm{Ma}$ & $2.11 \pm 0.02 \mathrm{Ma}$ & 0.5 & $316 \pm 42$ \\
\hline Senèze $101^{*}$ & 7 & & SEN 101 & $2.15 \pm 0.01 \mathrm{Ma}$ & $2.16 \pm 0.01 \mathrm{Ma}$ & $0.02 \mathrm{Ma}$ & 0.1 & 1.0 & $2.14 \pm 0.02 \mathrm{Ma}$ & $2.15 \pm 0.02 \mathrm{Ma}$ & 0.3 & $309 \pm 32$ \\
\hline Senèze $8^{*}$ & 7 & & SEN 8 & $2.16 \pm 0.01 \mathrm{Ma}$ & $2.18 \pm 0.01 \mathrm{Ma}$ & $0.02 \mathrm{Ma}$ & 1.3 & 0.3 & $2.16 \pm 0.02 \mathrm{Ma}$ & $2.18 \pm 0.02 \mathrm{Ma}$ & 1.2 & $291 \pm 6$ \\
\hline Senèze $98^{*}$ & 7 & & SEN 98 & $2.19 \pm 0.01 \mathrm{Ma}$ & $2.21 \pm 0.01 \mathrm{Ma}$ & $01 \mathrm{Ma}$ & 1.0 & 0.5 & $.19 \pm 0$. & $\mathrm{Ma}$ & 1.1 & $36 \pm 8$ \\
\hline Chilhac* & 7 & & CHILH. & $2.36 \pm 0.03 \mathrm{Ma}$ & $0.03 \mathrm{Ma}$ & $0.04 \mathrm{Ma}$ & 0.5 & & $0.05 \mathrm{Ma}$ & $5 \mathrm{Ma}$ & 15 & $77 \pm 4$ \\
\hline Perrier Avalanche $\mathrm{C}^{*}$ & 7 & & PER-51 & $2.58 \pm 0.01 \mathrm{Ma}$ & $2.60 \pm 0.01 \mathrm{Ma}$ & $0.02 \mathrm{Ma}$ & 1.0 & 0.8 & $2.59 \pm 0$. & $2.60 \pm 0$. & 0.6 & $4 \pm 40$ \\
\hline rrier Grottes (Ash fall) & & & PER 145 & $2.59 \pm 0.01 \mathrm{Ma}$ & $2.61 \pm 0.01 \mathrm{Ma}$ & $0.03 \mathrm{Ma}$ & 0.7 & 0.7 & Ma & $\mathrm{Ma}$ & 0.7 & $2 \pm 28$ \\
\hline rier Grottes ( $\mathrm{P}$ & & & PER 144 & $2.60 \pm 0.01 \mathrm{Ma}$ & $2.62 \pm 0.01 \mathrm{Ma}$ & $0.03 \mathrm{Ma}$ & 1.3 & 0.2 & $2.60 \pm 0$. & $2.62 \pm 0.03 \mathrm{Ma}$ & 1.4 & $300 \pm 9$ \\
\hline Vendeix 1000 flow & & & 08MD-03 & $2.67 \pm 0.01 \mathrm{Ma}$ & $2.69 \pm 0.01 \mathrm{Ma}$ & $0.04 \mathrm{Ma}$ & 1.6 & 0.1 & $2.67 \pm 0.05 \mathrm{Ma}$ & $2.69 \pm 0.05 \mathrm{Ma}$ & 1.3 & $302 \pm 8$ \\
\hline Perrier $\mathbf{F b}^{*}$ & & & PER-139 & $2.68 \pm 0.01 \mathrm{Ma}$ & $2.70 \pm 0.01 \mathrm{Ma}$ & $0.02 \mathrm{Ma}$ & 1.1 & 0.4 & $2 \mathrm{Ma}$ & $2.70 \pm 0.02 \mathrm{Ma}$ & 1.2 & $3 \pm 18$ \\
\hline uffite du Fournet" & & & PER-142 & $2.69 \pm 0.01 \mathrm{Ma}$ & $2.71 \pm 0.01 \mathrm{Ma}$ & $0.03 \mathrm{Ma}$ & 1.1 & 0.4 & $2.68 \pm 0.03 \mathrm{Ma}$ & $2.70 \pm 0.03 \mathrm{Ma}$ & 1.0 & $04 \pm 6$ \\
\hline Le Pessy-Pregnoux & & & 08MD-06 & $2.70 \pm 0.01 \mathrm{Ma}$ & $2.72 \pm 0.01 \mathrm{Ma}$ & $0.04 \mathrm{Ma}$ & 1.5 & 0.1 & $2.69 \pm 0.07 \mathrm{Ma}$ & $2.71 \pm 0.07 \mathrm{Ma}$ & 1.1 & $380 \pm 80$ \\
\hline Bourboule, haut & & & 08MD-04 & $2.73 \pm 0.01 \mathrm{Ma}$ & $2.75 \pm 0.01 \mathrm{Ma}$ & $0.04 \mathrm{Ma}$ & 1.3 & 0.3 & $2.74 \pm 0.08 \mathrm{Ma}$ & $2.76 \pm 0.08 \mathrm{Ma}$ & 1.4 & $0 \pm 92$ \\
\hline Vend & & & O8MD- -0 & $2.74 \pm$ & & & & 0.2 & & & . & \\
\hline Côte d'Ardé * (Etouaires) & 7 & & PER 105 & $2.76 \pm 0.01 \mathrm{Ma}$ & $2.78 \pm 0.01 \mathrm{Ma}$ & $0.02 \mathrm{Ma}$ & 1.2 & 0.3 & $2.76 \pm 0.02 \mathrm{Ma}$ & $2.78 \pm 0.02 \mathrm{Ma}$ & 1.3 & $296 \pm 4$ \\
\hline Bourboule, bas & & & 08MD-05 & $2.86 \pm 0.01 \mathrm{Ma}$ & $2.88 \pm 0.01 \mathrm{Ma}$ & $0.04 \mathrm{Ma}$ & 1.0 & 0.5 & $2.86 \pm 0.06 \mathrm{Ma}$ & $2.88 \pm 0.06 \mathrm{Ma}$ & 1.1 & $300 \pm 33$ \\
\hline & 8 & & N*A & $3.00 \pm$ & & $x_{-1}$ & NA & $\mathrm{c}_{\mathrm{s}}$ & & & & Wh \\
\hline Saill & 6 & $3.07 \pm 0.04 \mathrm{Ma}$ & & & 3. $4.2-5$ & $0 . C^{2}-1$ & 6.1 & 0.02 & N/A & N/A & $\mathrm{N}$ & \\
\hline eservoir Perrier, & 7 & & PER 128 & $3.09 \pm 0.01 \mathrm{Ma}$ & $3.11 \pm 0.01 \mathrm{Ma}$ & $0.02 \mathrm{Ma}$ & 1.3 & 0.3 & $3.09 \pm 0.02 \mathrm{Ma}$ & $3.11 \pm 0.02 \mathrm{Ma}$ & 1.4 & $294 \pm 6$ \\
\hline
\end{tabular}

1: Roger et al. (1999); 2: Nomade et al. (2012); 3: Pastre et al. (2007); 4: Lo Bello et al. (1987); 5: Nomade et al. (2010); 6: Féraud et al.(1990); 7: Nomade et al. (2013); 8: Lo Bello (1988) 